\title{
INVESTIGATING THE INSTRUCTOR'S ROLE IN NEW STUDENT SENSE OF CLASSROOM COMMUNITY
}

\author{
A Thesis \\ presented to \\ the Faculty of California Polytechnic State University, \\ San Luis Obispo
}

\author{
In Partial Fulfillment \\ of the Requirements for the Degree \\ Master of Science in Agriculture with a Specialization in \\ Recreation, Parks, and Tourism Administration
}

By

Alix Davidson

May 2012 
(C) 2012

Alix Elizabeth Davidson

ALL RIGHTS RESERVED 


\section{COMMITTEE MEMBERSHIP}

TITLE: Investigating the Instructor's Role in Sense of Classroom Community in First Year College Students

AUTHOR: Alix Davidson

DATE SUBMITTED: May 2012

COMMITTEE CHAIR: Jeffrey Jacobs, Ph. D., Recreation, Parks, and Tourism Administration

COMMITTEE MEMBER: Brian Greenwood, Ph. D., Recreation, Parks, and Tourism Administration

COMMITTEE MEMBER: Heather Smith, Ph. D., Statistics 


\begin{abstract}
Investigating the Instructor's Role in Sense of Classroom Community in First Year College Students
\end{abstract}

Alix Davidson

The purpose of the study is to determine whether an instructor's intentional effort to build community in his/her classroom results in a higher sense of classroom community among students. This study also examined what types of community building activities were conducted by each instructor and measured the students' responses to each different activity. This was intended to establish a preliminary set of best practices for creating classroom community. A two-part questionnaire, including an adapted version of the Classroom Community Scale, was administered to instructors $(n=5)$ and students $(n=113)$ enrolled in two or four unit courses at California Polytechnic State University. These courses were designed to introduce students to their chosen majors. One-way analysis of variance, and two-proportion tests were used to determine the relationship between instructor intentions and student sense of classroom community, and the differences in student sense of classroom community between courses. Findings indicate that what course a student was in was the significant factor in determining sense of classroom community. Additionally, students accurately perceived their instructor's intent to create classroom community.

Keywords: Sense of community, sense of belonging, team building, classroom community 


\section{TABLE OF CONTENTS}

LIST OF TABLES ............................................................................................... vii

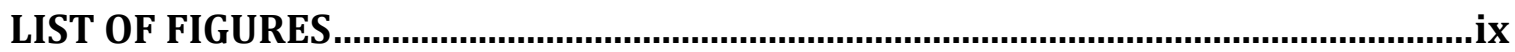

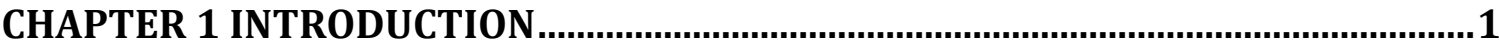

Background ....................................................................................................................... 1

Need for the Study ........................................................................................................... 4

Purpose Statement ................................................................................................................... 5

Research Questions............................................................................................................. 6

Delimitations.................................................................................................................... 6

Limitations....................................................................................................................... 7

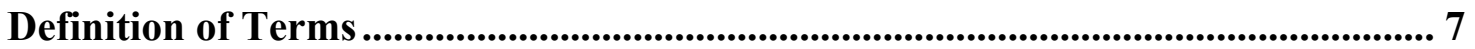

Summary.................................................................................................................................... 8

CHAPTER 2 REVIEW OF LITERATURE

Search Process ....................................................................................................................... 9

History ........................................................................................................................... 9

Sense of Community Theory .................................................................................... 10

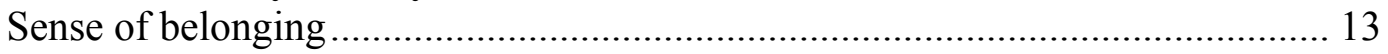

Territorial and relational community ............................................................ 14

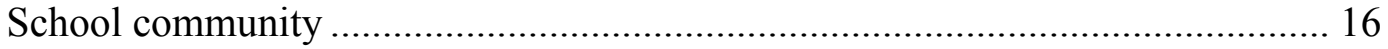

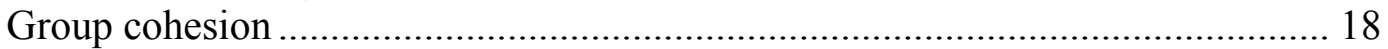

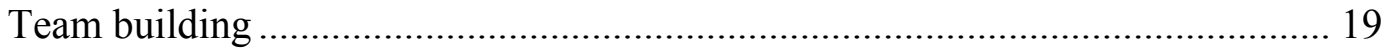

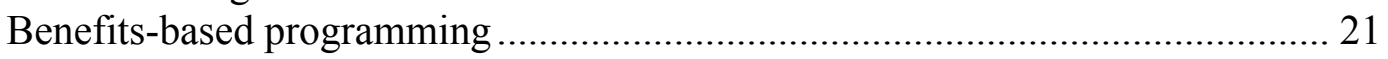

Role of the instructor ............................................................................... 22

Benefits of a Sense of Community ............................................................................... 23

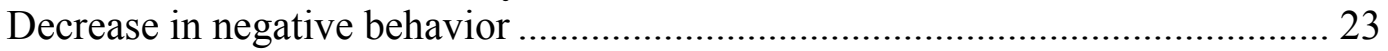

Psychological development ............................................................................ 24

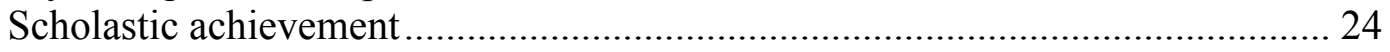

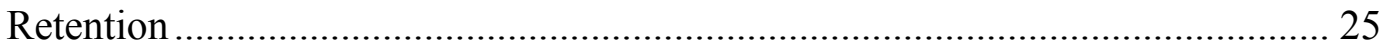

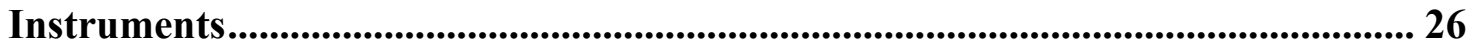

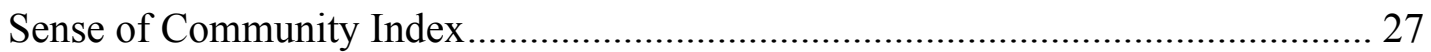

Social Connectedness Scale ............................................................................... 28

Classroom Community Scale and Classroom and School Community Inventory ... 28

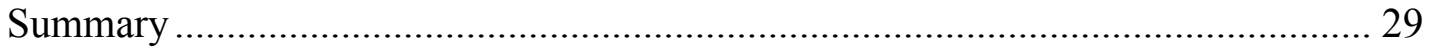

CHAPTER 3 METHODOLOGY........................................................................... 31

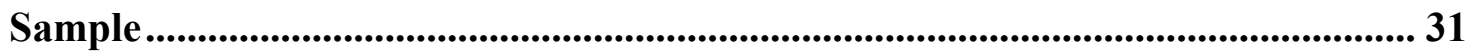

Instrument Selection .................................................................................................................. 32

Instrument Design ..................................................................................................................... 32

Pilot Study............................................................................................................................ 34

Human Subjects Review Procedures .................................................................................. 34

Data Collection ................................................................................................................................ 35

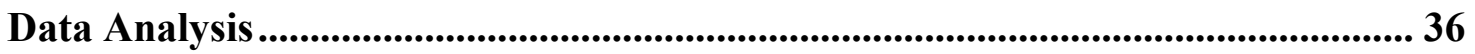




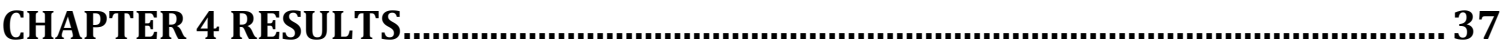

Participant Characteristics and Responses ............................................................... 37

Sense of Classroom Community .................................................................................. 38

Intent to Create Classroom Community ........................................................... 38

Community Building Activities ................................................................................. 41

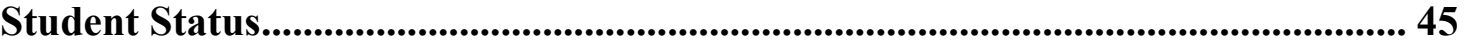

Number of Other Students Known Prior to the Class.......................................... 46

Time Spent on Activities........................................................................................................... 48

Activity Enjoyment .......................................................................................... 51

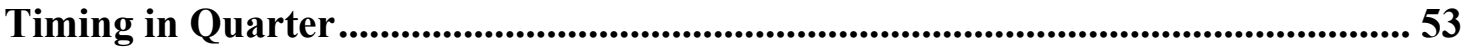

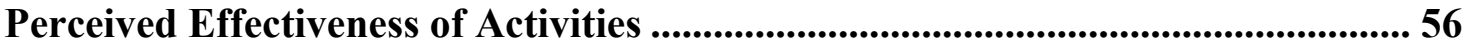

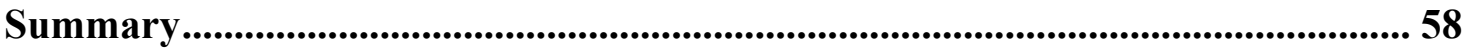

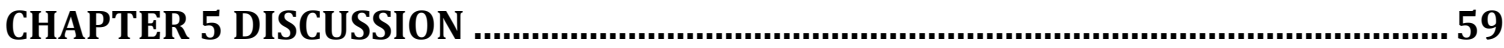

Summary of Background and Literature .......................................................... 59

Summary of Methodology .....................................................................................60

Summary of Results ................................................................................................. 61

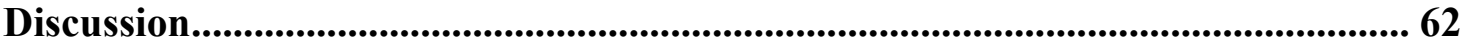

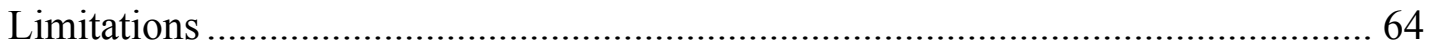

Conclusions ...................................................................................................... 64

Recommendations ......................................................................................................6 65

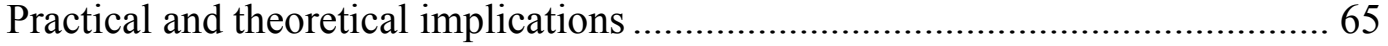

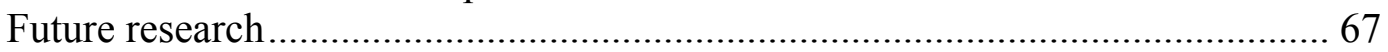

REFERENCES

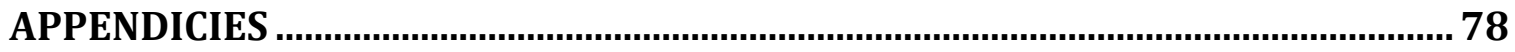

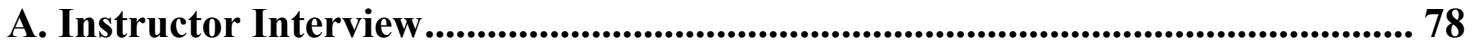

B. Student Questionnaire Script .................................................................................. 81

C. Student Questionnaire ....................................................................................... 83 


\section{LIST OF TABLES}

Table 1 Respondents by Course. 38

Table 2 Mean Sense of Classroom Community by Course.

Table 3 Mean Student Perception of Instructors intention to Create Classroom

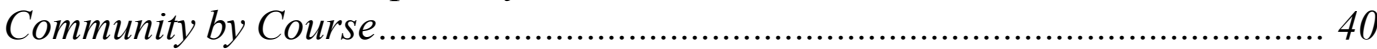

Table 4 Student Activity Type by Course ................................................................ 42

Table 5 Mean Sense of Classroom Community Score by Activity Type ....................... 44

Table 6 Student Status by Course ……………………........................................... 45

Table 7 Mean Sense of Classroom Community Score by Student Status..................... 46

Table 8 Number of Other Students Known Prior to the Class by Course ................... 47

Table 9 Mean Sense of Classroom Community Score by Number of Other Students

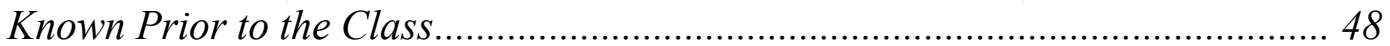

Table 10 Mean Time in Minutes Spent on Each Activity by Course ........................... 50

Table 11 Activity Enjoyment by Activity Type ………………………………….... 52

Table 12 Activity Type by Timing in Quarter …………........................................ 54

Table 13 Timing in Quarter by Course ............................................................... 55

Table 14 Mean Perceived Effectiveness and Mean Sense of Classroom Community

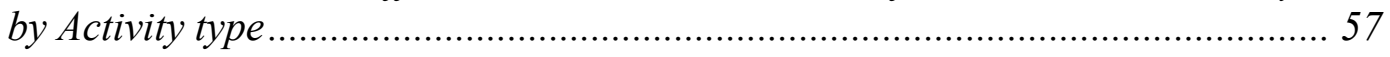




\section{LIST OF FIGURES}

Figure 1 Elements of Sense of Community and Their Hypothesized Relationships ..... 13 


\section{CHAPTER 1 INTRODUCTION}

The benefits of developing a strong sense of community are widely accepted and well researched. Exactly how to define and facilitate the development of this sense of community has proved more difficult for researchers. This thesis is the result of a study of community building activities conducted by Cal Poly professors and the effect of these activities on the participating students' sense of classroom community. The two-part study used interviews and questionnaires to determine the relationship between instructor-led activities and students' sense of classroom community. It serves as a step in determining the current state of intentional classroom community building at Cal Poly and the role that these activities play in new students' sense of classroom community. This study will also help to outline the types of activities that are most effective in building classroom community. This chapter presents the background and the need for the study, the purpose statement, research questions, a definition of key terms, delimitations, limitations, and a summary.

\section{Background}

There are many benefits to having a strong sense of community. These include retention, academic success, psychological development, and a decrease in negative behaviors. For first year and first time college students, the classroom represents a logical environment for community building activities. The average college freshman spends 16 hours per week in the classroom and additional time working on assignments and projects making the academic side of college a significant source of social interaction. When discussing first year students, perhaps the most frequently examined statistic is the rate of retention. 
According to the Beginning Postsecondary Survey (Institute of Education Sciences, 2009), from 2003-2009, colleges and universities in the United States experienced an average rate of attrition of approximately $35 \%$. Retention rates are often used as indicators of success for both students and their universities and, due in part to President Obama's goal of raising graduation rates, there has been a recent trend to introduce or reintroduce performance based funding to institutions of higher education (Dougherty, Natow, Bork, Jones, \& Vega, 2011). University administrators have responded to the pressure to retain students by developing numerous outreach programs to engage students, particularly freshmen. These programs range from retreats to extended orientations and have started to include freshman introductory courses. Retaining students remains a challenge at universities across the country, including California Polytechnic State University in San Luis Obispo, California. In 2009, Cal Poly boasted a $91 \%$ one-year retention rate. While this number is higher than the national average, it is still a number that school administrators strive to improve (Goodman, 2011). At Cal Poly, retention and graduation rates vary across the different colleges as do the efforts to academically and socially engage first year students.

In addition to retention rates, a strong sense of community has been linked to increased academic achievement (Sherblom, Marshall, and Sherblom, 2006). Test scores may be more important than retention rates when it comes to evaluating school and student success. Throughout the educational system, test scores are used as benchmarks of personal and school improvement. The No Child Left Behind Act of 2001 bases school funding on students' success on annual standardized tests, and SATs determine the fate of college-bound students and define the applicant pool. At Cal Poly, grades often determine 
a student's choice to remain enrolled. Of the $37 \%$ of students in the 1999 cohort (students who enrolled as freshmen in 1999) that did not return for a second year, over two thirds exited in poor standing with a GPA of under 2.00 .

The importance of a sense of community in college is not limited to retention rates and test scores. The benefits to the individual are profound. Ranging from a decrease in negative and destructive behaviors to boosts in self-esteem, feeling socially and academically connected to others is vital to success in college. Researchers and educational policy makers are actively trying to emphasize the importance of student engagement and community building in student satisfaction (Dick, Carey, \& Carey, 2005). This emphasis frequently focuses on integrating students' social and academic lives but the role of the instructor in this process must also be considered. Researchers have observed that instructors are instrumental in setting and maintaining the structures upon which classroom and school communities are built (Ritter, Polnick, Fink, \& Oescher, 2010).

Many of the most accepted models and scales developed to evaluate classroom community are based upon the framework of McMillan and Chavis' (1986) Sense of Community (SOC) Theory. The theory and the subsequently developed scales have shaped the landscape of sense of community research. The Sense of Community Index (SCI) is the mostly widely used and validated measure of SOC. Despite its ubiquity, the SCI has been criticized for not being a complete measure of sense of community (i.e., Chipuer \& Pretty, 1999; Long \& Perkins, 2003). A strength of the SCI, the fact that it is applicable in many settings is also a weakness, the scale suffers from a lack of specificity. As a result, a number of other scales have emerged to address particular areas of SOC, 
including those dedicated to school and classroom communities. In an effort to create a scale that is community-specific, Rovai (2002) developed the Classroom Community Scale (CCS). The CCS was designed specifically to examine sense of community in learning environments. The instrument was originally validated in online classrooms but Rovai insists that it is applicable regardless of the setting. Classroom community research is a mosaic of other fields and disciplines such as psychology, sociology, and education and researchers continue to strive to determine a definition and an adequate measure of the sense of classroom community.

\section{Need for the Study}

Cal Poly's population is constantly growing. Since 1990, the freshman class has grown in size by nearly 1,300 students, with the most recent census, in 2009 , reporting 3,098 first time freshmen (California Polytechnic State University). An additional 716 transfer students make new students a large part of the Cal Poly community. The evergrowing number makes engaging these new students, and ensuring that they are connected to each other, more difficult and more essential. Cal Poly administrators have reached out to new students by creating several programs such as a freshman orientation known as "Week of Welcome" and peer leadership programs. Some departments have also established optional or required classes designed to introduce students to their chosen major. The present study aimed to investigate the effectiveness of these introductory courses in building classroom community and camaraderie amongst first time students. The study can help Cal Poly administrators and professors understand the types of community building activities that are the most successful. 
A sizable amount of recent classroom community research has been conducted in online or hybrid classes (i.e., Overbaugh \& Nickel, 2011; Ritter et al., 2010 etc.). Even the study Rovai (2002) conducted to establish the CCS was piloted and validated in virtual classrooms. In a study of graduate student perceptions of learning and classroom community Ritter, Polnick, Fink, and Oescher compared the responses of students in online, hybrid and face-to-face classrooms. Many of the studies of face-to-face settings have focused on elementary or secondary schools (i.e., Libbey, 2004; Voelk1, 1996; Goodenow, 1993) or have been more broad-based in investigating school climate and community as opposed to concentrating on classroom communities. Although the sense of community created in learning environments has been established as an important factor in many areas of student engagement and development, the methods and process for establishing community are often overlooked or assumed.

This study differed from previous studies of classroom community, as data for this study were collected specifically from college students, primarily those in their first year of college. Unlike the majority of recent studies, this study examined only face-toface classes. Additionally, this study asked instructors as well as students about the tactics used to create classroom community. As opposed to focusing on one particular area of study, data were collected from various classrooms across several disciplines. This study also differed from a majority of classroom community research, as it focused on the methods of establishing a strong sense of community rather than concentrating on the benefits derived.

\section{Purpose Statement}

The purpose of the study was to determine whether an instructor's intentional effort to build community in his/her classroom results in a higher sense of classroom 
community among students. This study also examined what types of community building activities were conducted by each instructor and measured the students' responses to each different activity. This was intended to establish a preliminary set of best practices for creating classroom community.

\section{Research Questions}

This study investigated the following research questions:

1. Do instructors at Cal Poly intentionally design activities to build sense of community in their classrooms?

2. Do students whose instructors feel that they create classroom community "to a great extent" have higher Classroom Community Scale scores than students whose instructors indicate that they create classroom community "quite a bit"?

3. Do certain intentionally designed activities result in a higher sense of classroom community among first time, first year students than other activities?

4. Do instructor intent and student sense of classroom community vary significantly among disciplines?

\section{Delimitations}

This study was delimited to the following parameters:

1. Limited to instructors and students in 2-4 unit major introductory classes at California Polytechnic State University, San Luis Obispo.

2. Data collection took place at the end of fall quarter (December), 2011.

3. Limited to English speaking/literate students and professors. 
4. Limited to professors who volunteered their classes for participation.

5. Limited to students present on the day of data collection.

6. Limited to students who volunteered to participate.

\section{Limitations}

This study was limited by the following factors:

1. Four instructors volunteered their classes for participation.

2. With the exception of the Classroom Community Scale, the instrument was not tested for reliability or validity.

3. Data gathered from this study was based on self-reported questionnaires.

\section{Definition of terms}

First year, first time student. A student who has matriculated for the first time at Cal Poly in a given quarter.

First year student. A student who is new to Cal Poly in a given quarter but who has matriculated at another college or university in the past.

Psychological Sense of Community. "The sense that one [is] part of a readily available, mutually supportive network of relationships upon which one [can] depend and as a result of which one [does] not experience sustained feelings of loneliness...it is not merely a matter of how many people one knows" (Sarason, 1974, p.1-2). Classroom Community. the feeling that members of a classroom have that they belong, trust others in the class, that they matter to others in the class, that they possess a shared faith that their educational needs will be met through their 
commitment to the shared goals and values of other students at the school (Rovai, Wighting, \& Lucking, 2004).

Community building activities. Any activity that the professor or student perceives was conducted with the intention of helping the class bond.

Classroom Community Scale. A measure of classroom community (Rovai, 2002).

Retention. When a student enrolls in courses for the fall quarter immediately following their first year of college.

\section{Summary}

This study examines the sense of classroom community felt by first time, first year students in major introductory courses at California Polytechnic State University in San Luis Obispo, California. The study also investigates the community building activities and techniques conducted by the instructors of these courses. The results of this study can be used in further research to determine the activities that are the most effective in building community. 


\section{Chapter 2-Review of Literature}

There is a large body of research, primarily from the field of psychology, devoted to defining and describing Sense of Community (SOC). This chapter includes a review of the literature relevant to the study. It will also describe the search process, and clarify and define the theories and concepts central to the study. Many of these theories and concepts are used interchangeably and are a ubiquitous and confusing portion of community and educational psychology.

\section{Search Process}

The following review is a result of a search of the literature from the fields of community, educational, and developmental psychology. The search was performed primarily through online databases accessed through California Polytechnic State University San Luis Obispo. Online journals devoted to community psychology provided a majority of the articles about theoretical and empirical studies reviewed in this chapter. The keywords used to search were: sense of community, classroom community, sense of belonging, student retention, college students, school community, place attachment, and instructor.

\section{History}

Sense of Community (SOC) research is rooted in community psychology and was advanced by Sarason (1974). Sarason described the "Psychological Sense of Community" as,

"the sense that one was part of a readily available, mutually supportive network of relationships upon which one could depend and as a result of which one did not 
experience sustained feelings of loneliness... it is not merely a matter of how many people one knows" (p. 1-2).

Sarason explained that SOC is not simply a measure of the number of friends or acquaintances one has and emphasized the idea that SOC refers to closeness and connectedness in daily life. Sarason also conceded that although SOC was difficult to define, people knew when a sense of belonging existed in their communities.

Since its introduction into the field, researchers have struggled to develop a definition for the psychological sense of community (PSC). Sarason expressed the difficulty of what he meant by PSC. While research supports the relatively logical connection between an individual's SOC and their well being, a universal definition or scale to measure SOC has yet to be developed (Chipuer \& Pretty, 1999). The most widely used measure of SOC is the Sense of Community Index developed by Chavis, Hogge, McMillan, \& Wandersman in 1986.

\section{Sense of Community Theory}

McMillan (1976) and McMillan and Chavis (1986) proposed a definition of SOC, "sense of community is a feeling that members have of belonging, a feeling that members matter to one another and to the group, and a shared faith that members' needs will be met through their commitment to be together" (p. 9). McMillan and Chavis' definition focuses on group membership while Sarason's definition emphasizes the benefits to the individual. McMillan and Chavis further dissected their definition into four elements. The first element is membership-the feeling of belonging. The feeling of belonging and "insideness" is a common factor when discussing SOC (Rowles, 1983) and is even regarded as a fundamental motivator for human behavior (Baumeister \& Leary, 1995). 
An important, and potentially controversial aspect of the membership element, is the clause which introduces boundaries as a necessity for membership. McMillan and Chavis struggle with group members' requirement of boundaries as a safety concern versus the isolation and exclusion caused by these very boundaries. Also included in the membership construct are the attributes of emotional safety, sense of identification, personal investment and a common symbol system.

The second element of SOC is influence. This definition of influence refers to a "bidirectional concept" (McMillan \& Chavis, 1986, p. 11) of the word. The first direction dictates that in order for a member to be attracted to the group, this member must have some influence over the group's behavior. The other direction explains that in order for a group to be cohesive, it is necessary that the group have influence over its members. Mutual trust, McMillan and Chavis (1986) added, is also a vital component of influence.

The third element is the integration and fulfillment of needs. This somewhat complex concept, McMillan and Chavis (1986) explained, ultimately describes reinforcement-that people will have a SOC when their needs are met by other community members. The researchers attested that, "a strong community is able to fit people together so that people meet others' needs while they meet their own" (p. 13).

The final element of SOC is shared emotional connection. The shared emotional connection can be achieved in a number of ways but primary examples are increased interaction, high-quality interaction, closure to events, shared valent events, investment in the community, honor versus humiliation of community members, and a spiritual bond. McMillan and Chavis (1986) proposed that the more frequent the interactions between community members, the closer these members will become. Closure to events explains 
that group cohesiveness increases with successful completion of a task and is compromised when these goals are unresolved. Investment in the community implies that the more time an individual commits to the community, the more important that community becomes to the individual. The effect of honor vs. humiliation explains that if a community member is honored by their community they will feel more attracted to that community whereas an individual who has been humiliated by their community will feel less attracted. Lastly, spiritual bond describes the degree to which community members feel they share a spiritual connection. McMillan and Chavis proposed that satisfaction in these four interrelated elements indicates a SOC (Figure 1). 
I. Membership

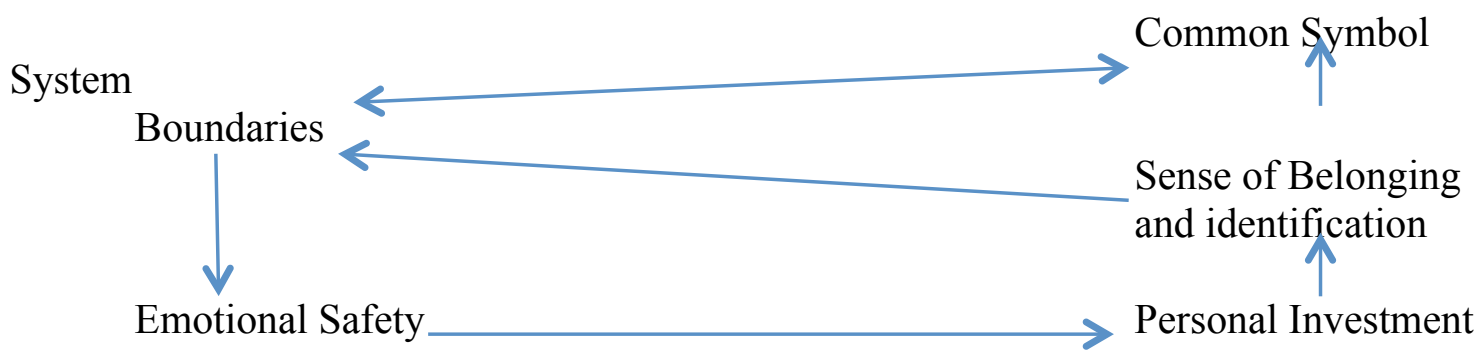

II. Influence

A. Member openness to influence by community members $\quad$ Power of member to influence the community.

B. Member need for consensual validation x community's need for conformity $=$ community power to influence members (community norms).

III. Integration and Fulfillment of Needs

A. To the degree that communities successfully facilitate person-environment fit (meeting of needs) among members, members will be able to develop sense of community.

IV. Shared Emotional Connection

A. Formula 1: Shared emotional connection $=$ contact + high-quality interaction. B. Formula 2: High-quality interaction=(events with successful closure ambiguity) $\mathrm{x}$ (event valence $\mathrm{x}$ sharedness of the event) + amount of honor given to members - amount of humiliation.

Figure 1

Elements of Sense of Community and Their Hypothesized Relationships. Reprinted from "A Sense of Community: A Definition and Theory", by D.W. McMillan and D.M. Chavis, 1986, Journal of Community Psychology, volume 14, p. 15

Sense of belonging. Though SOC has its background in the field of community psychology, the idea of a sense of belonging is hardly limited to the development of communities but in fact is famously and historically linked to the development of the individual. Maslow's (1943) widely accepted hierarchy of needs listed love or social 
needs as an essential tier in human development. Maslow stated that once physiological and safety needs are gratified, an individual "will hunger for affectionate relations with people in general, namely for a place in his group, and he will strive with great intensity to achieve this goal" (p. 12). Maslow considered belonging to be vital to healthy human development and that the "thwarting" of the love needs is central to "maladjustment and more severe psychopathology" (p. 12).

Similarly, Baumeister and Leary (1995) purported that the need to belong-which they defined as the "need to form and maintain...interpersonal relationships" (p. 3)-is innate. They explained that the need to belong should be within all humans in any culture and, though expression of this need can be expected to vary, complete removal of the need from any individual or community would prove impossible. Motivational researchers suggest that, in addition to autonomy and competence, relatedness-the need to belong-is essential to human development (Connell \& Wellborn, 1991; Deci, Vallerand, Pelletier, \& Ryan, 1991; Ryan, 1995).

Territorial and relational community. Although McMillan and Chavis' (1986) often referenced definition and model of SOC refers exclusively to a feeling of belonging, literature about community psychology has tended to focus on the physical constraints of community. Tartaglia (2006) suggested that McMillian and Chavis' model was incomplete as it did not acknowledge place attachment as an important factor of SOC.

There are two primary uses of the word community, one being the territorial sense and the other being the relational (Gusfield, 1975). Community is frequently studied on the regional level with researchers identifying differences in SOC between large cities 
and smaller towns (Glynn, 1981; Davidson \& Cotter, 1991; Prezza \& Costantini, 1998). Researchers have also looked to neighborhood attachment as determined by such factors as length and commitment to residency (i.e., owning versus renting a home) as a reflection of residents' SOC (Riger \& Lavrakas, 1981). Studies on territorial communities often include an analysis of disruption to place attachment (Tuan, 1974; Relph, 1976). While many of these early studies revolve around adults in the neighborhood community, Chawla (1992) offered an explanation of childhood place attachment stating that children are attached to a place when they are happy being there and display or feel distress when leaving. Chawla also stated that, for a child, place attachment depends on valuing a place for the satisfaction of physical needs and for its own intrinsic qualities.

Although frequently studied as separate entities, researchers have acknowledged that the two concepts of community, the territorial and the relational, are inextricable especially today when virtual communities are becoming the norm and a common physical space is not a required component of community (Reich, 2010). Because it is so challenging to separate territorial community-the SOC achieved by attachment to placefrom the social aspects of sense of relational community, Cuba and Hummon (1993) proposed that a more comprehensive view of community is needed, one that includes analysis not only of attachment to physical space but also demographic and social aspects of community since SOC is not necessarily contingent on the stability of place (Fried, 1982). Although seemingly slightly overlooked in the literature of community and place attachment, the relational sense of community is hardly a new concept as Durkheim (1951) noted that communities are more often developed around interests and skills rather 
than locality. Other researchers have explored the idea of relational community using different terms such as social bonding (Riger and Lavrakas).

School community. Much like SOC research in general, there have been numerous attempts to define SOC in the school setting. Many researchers have settled on the basic definition that a there is a SOC within a school or a classroom when members (students and staff) "(a) know, care about, and support one another, and (b) have the opportunity to participate actively in classroom decision-making, planning, and goal-setting" (Solomon, Watson, Battistich, Schaps, \& Delucchi, 1996, p. 722). Bryk and Driscoll (1998) extended this definition to include elements such as shared values, a common agenda, and a caring environment. Despite slight differences, all of the definitions of school and classroom community include the essential elements of trust, interactivity, mutual interdependence, and common expectations (Shaffer \& Anundsen, 1993). Researchers agree that SOC in schools may be important to the members' quality of life as well as important to their satisfaction with their work /school environment, motivation and achievement (Goodenow, 1993; Arhar \& Kromrey, 1993; Battistich, Solomon, Kim, Watson, \& Schaps, 1995). Zimmerman and Arunkumar (1994) cited SOC as being vital for community members' resiliency in and out of the school community.

Although research on the topic of SOC is typically based on geographic communities such as neighborhoods (i.e., Prezza \& Costantini, 1998; Whitlock, 2007; Obst, Smith, \& Zinkiewicz, 2002), there is a significant amount of information on school and classroom communities. Reformers in the educational community have long recognized the importance of community within schools and classrooms; Dewey (1958) suggested that 
quality of an education is exemplified by a community formed by the teachers and students.

The field of psychology has developed a number of other terms central to the concept of community, these include: connectedness, attachment, engagement, and bonding (Libbey, 2004). In a study of student relationships to their school, Libbey attempted to define over ten of these related-yet distinct-ideas. Aside from the lack of consensus on a definition or a theory of SOC, Libbey explained that the indiscriminate use of these terms has "created an overlapping and confusing definitional spectrum" (p. 1). Beyond providing definitions and explanations of several of the terms common to school attachment studies the article attempts to briefly discuss the measurement scales for each of the terms described. Libbey explained that the goal of her article was not to conclude on one overarching term but rather to summarize relevant literature to clarify the various definitions.

Throughout the article, Libbey exposed a theme found in her research; she identified nine constructs that relate to, and perhaps predict, school connectedness. School connectedness is briefly defined as an overarching concept measuring commitment, power, belonging, and belief in rules (Brown \& Evans, 2002). These four aspects of school connection are narrowed down from earlier research that included items about liking and looking forward to school (Eccles, Early, Fraiser, Belansky, \& McCarthy, 1997). While Libbey pointed out that none of these constructs had been proven to be more influential than another, she stated that all of the constructs had been compared to affective outcomes such as belonging as well as to functional outcomes such as grades, and that all of the constructs are salient in both of these realms. Despite the wide variety 
of measures and methods used to determine students' attachment to their schools, Libbey concluded that, "whether examining academic performance or involvement with a range of health behaviors, young people who feel connected to school, that they belong, and that teachers are supportive and treat them fairly, do better"(p.9).

The aforementioned concept of belonging has a place in the area of school and classroom community. Within the school context, Voelkl (1996) is credited with creating the most comprehensive measure of belonging; she included questions focused on school pride and identified differences between gender and racial differences. Although developed using students in the eighth grade, the Identification With School Questionnaire is effective in determining sense of belonging and value in students of all ages (i.e., Nasir, Jones, \& McLaughlin, 2011; Maras, 2007).

Group cohesion. Reflecting a common theme in community psychology, group cohesion is another construct that lacks a universal definition (Casey-Campbell \& Martens, 2008). Many definitions focus on the idea of group members' forging social bonds and remaining united (i.e., Carron, Widmeyer, \& Brawley, 1988). Serrano and Pons (2007) identified group cohesion as critical to the classroom performance. Recently, researchers have de-emphasized the importance of settling on a common operational definition of group cohesion, highlighting instead the value of matching the measurement of cohesion to the theoretical definition (Dion, 2001; Friedkin, 2004). The large number of definitions and related fields of research have produced an equally large number of scales and measurements used to assess group cohesion. This has resulted in each study being applicable only to specific schools of thought thus limiting generalization (CaseyCampbell \& Martens, 2008). 
Researchers explain that there are a number of antecedents or conditions that make groups and group members more likely to bond. These characteristics include structural factors such as group size and diversity (van Knippenberg \& Schippers, 2007) as well as member features such as intent to remain in the group (Cartwright \& Zander, 1968) or a high need for belonging (Cropanzano, Byrne, Bobocel, \& Rupp, 2001). Much like other constructs of SOC, group cohesion is often assumed to result in positive outcomes (Casey-Campbell \& Martens, 2008). This assumption has implications such as an increased focus on group cohesion especially for groups interested in increased productivity. Unfortunately, it also means that many programs designed to enhance group cohesion are created without empirical research proving their value (Shaw, 1981). Among the most common and popular ways of establishing group cohesion is through team-building.

Team building. Over the past three decades team building has become the most common group process intervention but there is a lack of consensus and limited and inconsistent findings as to the efficacy of team-building activities (Klein et al., 2009). There has been a recent call for researchers to focus on the particulars of team building. Specifically, understanding if and why team building works (results in positive outcomes), and under what conditions is it the most effective (Salas, Rozell, Mullen, \& Driskell, 1999). Team building is used in a wide variety of settings ranging from youth development (i.e., Bruner \& Spink, 2011; Bloom, Loughead, \& Newin, 2008) to corporate workplaces (i.e., Birx, Lasala, \& Wagstaff, 2011; Greffrath, Meyer, \& Monyeki 2008). The definition of team building has been debated but has retained generally the same form throughout the literature. There is now a consensus that there are four distinct 
models of team building that have not changed much throughout the history of the literature: a) goal-setting b) developing interpersonal relations c) role clarification and d) problem-solving (Klein et al., 2009).

Within the framework of these models team-building activities are frequently linked to potential outcomes. In the educational and especially corporate worlds, the desired outcome is often increased or enhanced performance. There have been a relatively large number of reviews of papers and studies spanning the history of team building literature (i.e., Woodman \& Sherwood, 1980; Buller, 1986; Salas, Rozell, Mullen, \& Driskell, 1999, Klein et al., 2009). These previous qualitative reviews describe the effect of team building on performance as inconclusive and unsubstantiated. On the other hand, many reviews and studies reveal positive results when team-building activities are related to subjective or affective outcomes. The models that were the most significant to the affective outcomes were generally goal-setting and role clarification (Klein et al., 2009). These reviews revealed that the larger the group, the greater the benefit from team building and that in order for team building to be the most effective each individual group must identify team characteristics and specific problems.

In contrast to the large number of reviews, there are a small number of empirical studies on the types of team building activities and their efficacy. Among the few methods that have been tested empirically and have been initially successful, are the methods of establishing homogenous theme groups (Agazarian, 2001), and collaborative story building and telling (CSBT) (Tradewell, Reisch, Travaglini, \& Kumar, 2011). CSBT allows a group to create a group narrative based on each individual's own experience. This method has been useful in classrooms and therapy groups, with stories 
frequently focusing on reframing social and cultural stereotypes. Despite the lack of empirically tested methods, variety and diversity of methods is important. Researchers are united in the fact that not all teams benefit from the same team building interventions (Klein et al., 2009).

Benefits-based programming. Although Libbey and other researchers agreed that supportive teachers or instructors are integral to participants' success, there are very few studies that focus on the community within an individual classroom. Of the studies focused on classroom community, there are even fewer which examine specific teacher actions or behaviors that promote a sense of classroom community. One way that the role of the instructor can be measured and related to participant outcomes is through benefitsbased programming (BBP). BBP provides a framework for organizations or schools to implement a measurement plan to track the success of their programs. BBP describes the practice of intentionally designing programs to measure whether, and to what degree, organizations and participants are meeting pre-established outcomes. Benefits-based programming focuses program provider and participant efforts on achieving and producing these certain outcomes as a result of participation (Walker, Deng, \& Dieser, 2005). Benefits-based programming, as proposed by Allen, Stevens, Hurtes, and Harwell (1998), consists of a four step plan; targeting outcomes, designing programs to impact these outcomes, assessing the programs' effectiveness, and disseminating the results.

$\mathrm{BBP}$ is applicable to a wide range of programs and agencies and a small number of similar practices have been created to address specific programs such as schools. Solomon et al. (1996) studied the Child Development Project (CDP). The CDP was a program implemented school-wide in several schools as well as in a number of individual 
classrooms. The CDP was designed to measure a number of teacher interventions aimed at creating an increased SOC in the classroom environment, the school-wide environment and through the home-school connection. Solomon et al. based the creation of the program on the assumption that the implementation of the predesigned interventions would lead to a heightened SOC and that this heightened SOC would lead to positive effects for students. The program intended to provide students with the environment and experience essential to developing a SOC. The CDP placed an emphasis on interventions planned to address the following elements and outcomes: cooperative learning, developmental discipline, interpersonal helping and other prosocial activity, the use of literature and other means to promote discourse about prosocial values, and to promote empathy and interpersonal understanding. Researchers concluded that the program was successful in heightening participants' SOC, which was strongly associated with affective variables such as liking for school and self-esteem. Aside from a heightened SOC Solomon et al. also linked program involvement with students' orientation towards others in areas such as conflict resolution and social understanding. While this project was implemented in elementary schools as opposed to university classrooms, the outcomes are not age specific and it is good evidence that intentional interventions on the part of the educational institution and teachers lead to heightened SOC and the associated benefits.

Role of the instructor. Ritter, Polnick, Fink, and Oescher (2010) used the Classroom Community Scale to compare perceived SOC across online, hybrid, and face-to-face classrooms. Ritter et al. explained that establishing a classroom community is the responsibility of the professor regardless of setting. In addition to establishing classroom 
goals, ethics, liabilities, communication styles and other expectations, the professor has the responsibility of establishing classroom norms, which are essential to the creation of classroom community. Professors are responsible for balancing social and community building requirements with content related material. Regardless of the format of the class, instructors set the tone at the beginning of the course, by allowing the opportunity for introductions so that the students and instructors can become familiar with each other.

\section{Benefits of a Sense of Community}

Decrease in negative behavior. When it comes to linking child and adolescent development to their SOC, the school community provides what seems like a clear forum for research yet there is a lack of investigation when it comes to exploring these connections (Battistich \& Hom, 1997). In Battistich and Hom's study of sense of school community and students' involvement in problem behaviors, they discovered that increased levels of school sense of community were associated with decreased student drug use and delinquent behavior. In a similar study exploring school adjustment and alcohol use, researchers determined that school populations with a high level of school adjustment reported lower levels of alcohol consumption (Henry, Stanley, Edwards, Harkabus, \& Chapin, 2009). Many studies on community as an intervention revolve around children (Evans, 2007) but a study on the role of community service in adolescent groups identified that the greater the number of school based organizations in which students were involved during their adolescence, the less likely they were to display socially negative behaviors in the years to follow (Youniss, McLellan, Su, \& Yates, 1999). 
Psychological development. Other than abating problem behaviors, a strong SOC also contributes to an individual's psychological well-being. In a study of the relationship between SOC and subjective well-being, Davidson and Cotter (1991) found that a SOC contributes to people's happiness as well as their perceived efficacy when dealing with personal issues or setbacks; their ability to cope. Youniss, Yates, and Su (1997) also discovered that students more involved in their community and community service were less likely to drop out of school than students who were less involved in the community. In a developmental context, SOC has been correlated to such benefits as: increase in perceived social support (Prezza \& Costantini, 1998), self-esteem (Prezza \& Costantini; Barber, Eccles, \& Stone, 2001), social development, and academic strength (Hansen, Larson, \& Dworkin, 2003). In a longitudinal study of youth community involvement Busseri, Rose-Krasnor, Willoughby, \& Chambers (2006) found that "greater breadth and intensity" of youth involvement is positively associated with successful youth development (p. 1323) which Baltes (1997) defined as the maximization of desired outcomes coupled with the minimization of undesired outcomes.

Scholastic achievement. Dewey's (1958) claim that a successful education is rooted in the successful formation of a school community is substantiated by more recent research from the community psychology and education fields. There is a conflict, however, in the educational system, between the importance of promoting a high SOC and the importance of improving academic achievement (Shouse, 1996; Osterman, 2000). Although educational reformers emphasize community building and encourage intraschool collegiality, the conflict is evidenced by the ever-growing importance of measures of scholastic aptitude such as standardized testing. Shouse explored whether these two 
different educational philosophies can work congruously, whether schools that focus on community building and social engagement can also produce high academic achievement. The research uncovered that the schools where a SOC was a result of "a strong sense of academic purpose" (p. 66), were the most effective. Despite Shouse's analysis, evidence exists to support the idea that school programs that focus on group cohesion, identity, and personal relationships between all members of the school community do well academically (Sherblom, Marshall, \& Sherblom, 2006; Hargreaves, Earl, \& Ryan, 1996). Sherblom, Marshall, and Sherblom showed that, at the high school level, reading scores showed the most improvement when students reported the presence of variables such as a high sense of well-being, high concern for others, and high feelings of belonging. According to Israel, Lionel, Beaulieu, and Hartless (2001), community social capital, including more interactions with extra-familiar adults, contributes to students excelling in school. In addition to higher test scores and increased grade point averages, a higher sense of community has been related to decreased instances of burnout in school and in professional settings (Chipuer \& Pretty, 1999).

Retention. The most frequently referenced and accepted model of the process of student retention and attrition is Tinto’s (1975) Student Integration Model (SIM). Tinto applied several different theoretical frameworks to develop a model for dropout from higher education, these range from Durkheim's (1951) Theory of Suicide to an economic theory of cost-benefit analysis. The SIM is a longitudinal model that analyzes a student's decision to drop out from higher education based on the interactions between each student's social and academic environments. The model accounts for students' individual characteristics and backgrounds, academic integration, and social integration. Tinto 
defined social integration as the relationship between one student with one set of characteristics with other students of varying characteristics within the school. Along with extracurricular and co-curricular social activities, social integration occurs though interaction with faculty within the school. Tinto concluded that, "social integration should increase the likelihood that the person will remain in college" (p. 107). Early research on the topic of student attrition explains that while social integration is an important factor in student persistence, the student's perception of their social support system is more directly related to a student's decision to stay in college (Pervin, Reik, \& Dalrymple, 1966; Rootman, 1972). More recently, researchers have supported Tinto's conclusions moving beyond the theories and empirically relating a student's ability to form social attachments to their peers and to faculty to persistence and degree attainment (Astin 1984; Johnson et al., 2007). While much of this research relates more directly to friendships than to connections made within the classroom, the studies are clear in suggesting that students with friendship and support from those with similar interests and similar characteristics are more likely to stay in school. These common interests and characteristics are often manifested in the course of study a student chooses.

\section{Instruments}

Sense of Community Index. Since McMillan and Chavis (1986) published their Sense of Community theory and model, the bulk of the related research has used and attempted to validate the SOC Index (SCI). Chavis, Hogge, McMillan, and Wandersman (1986) created the SCI using the Brunswik Lens model to test neighborhood PSC in adults. The SCI is based on the four elements of SOC outlined by McMillan and Chavis: membership, influence, integration and fulfillment of needs, and shared emotional 
connection. The SCI is a scale based on perceived SOC, because although SOC research was ubiquitous, there was no previous empirical testing of the construct and no other research or testing was rooted in theory (Chavis et al., 1986). Like many SOC researchers, Chavis et al. lamented the lack of a universal definition of SOC and chose to base their scale on the definition and model from McMillian and Chavis. The scale includes items related to the four elements as well as a number of unrelated items such as demographic information. The researchers found that the scale items designated for membership were the most related to perceived SOC. Chavis et al. noted that the SCI has limited validation due to a correlation of only .52 between results on the SCI and respondents self-reported SOC. At the time, the research team indicated that these results did not necessarily mean that the SCI is a flawed scale but just that it might be missing a few key clues to SOC. At very least, the researchers concluded, that the results demonstrate that McMillan and Chavis' theory is adequate in explaining SOC.

Chipuer and Pretty (1999) completed analyses of the SCI by examining factor structure and internal reliability across a variety of communities and age groups. The researchers explored the need for coherence in PSC research and hypothesized that this coherence could be accomplished by creating scales based on an overall framework. Many researchers express a preference for the SCI as it is one of the few scales of SOC grounded in PSC theory (Chipuer \& Pretty, 1999). Along with Chipuer and Pretty, a number of other researchers (Long \& Perkins, 2003, Berger, 1997) concluded that the SCI could provide a good foundation for scale development across different communities and age groups (p. 653) but that the SCI does not necessarily accurately measure the four elements of SOC and is better used as a one dimensional scale. 
Social Connectedness Scale. In addition to the SCI, a number of other scales have been developed to measure items closely related to SOC. Lee and Robbins (1995) worked to develop two valid and reliable self-report measures of aspects of belonging. Like the SCI, the scales were rooted in psychological theory, based on Kohuts' Self Psychology Theory (1984). The first scale, the Social Connectedness Scale, is based on three aspects of belongingness: connectedness, affiliation, and companionship and is related to one's opinion of oneself in relation to others. The other scale, the Social Assurance Scale, is based on one's reliance on others.

\section{Classroom Community Scale and Classroom and School Community Inventory.}

The Classroom Community Scale (CCS) was developed to be used by educational researchers in traditional and distance learning classrooms to identify useful course design and instruction to promote community development. Although the study was based on virtual classrooms, Rovai (2002) stated that the factors that create a SOC do not depend on the setting. Critiques of the CCS and other school community scales reveal that most measurements do not differentiate between the sense of classroom community and the sense of school community. The Classroom and School Community Inventory (CSCI) was created in response to these criticisms (Rovai, Wighting, \& Lucking, 2004). This suggests that students have multiple senses of community related to the various communities of which they are a part. The CSCI is also able to determine statistically significant differences between the SOC felt by online and traditional students, something that other measures do not address. 


\section{Summary}

SOC research has its foundations in the field of community psychology but is used in and influenced by many other areas of research. Among the many accepted definitions of SOC is, "a feeling that members have of belonging and being important to each other, and a shared faith that members' needs will be met by the commitment to be together" (McMillan \& Chavis, 1986). From this definition, McMillan and Chavis (1986) developed the SOC theory and Sense of Community Index (SCI), a measurement tool. The theory included the four components of SOC: membership, influence, integration and fulfillment of needs, and shared emotional connection. Despite the fact that the SCI has been validated and is the most widely used scale of SOC, the four components have been proven as unreliable measures when taken individually. When the four components are combined and considered as one dimension, however, the measure upholds its validity.

SOC is often used in conjunction with other terms to describe the human need to belong. These terms include sense of belonging, connectedness, affiliation, engagement, and bonding. Many researchers view the need to belong and experience social contact as fundamental (i.e., Baumeister \& Leary 1995). Much of the SOC research focuses on the benefits of community membership. These benefits include healthy psychological development such as increased in self-esteem (Prezza \& Costantini, 1998) and resiliency (Davidson \& Cotter, 1991). When applied in the school setting, a strong SOC is positively linked to measures of academic success, especially retention (Tinto, 1975) and higher grades (Hansen, Larson, \& Dworkin, 2003). 
SOC research has frequently revolved around territorial communities such as neighborhoods. In terms of educational communities, classroom community research at the university level has most recently been used to examine virtual or online learning environments (i.e., Ritter, Polnick, Fink, \& Oescher, 2010). Research on university students also has developed in areas outside of the classroom including residence halls (i.e., Berger, 1997) or extracurricular clubs (i.e., McCarthy, Pretty, \& Catano, 1990). These studies frequently focus on a predetermined outcome e.g. retention. Absent from the literature is the investigation of SOC in face-to-face university classrooms.

Evidence exists that regardless of what it is called, the idea of SOC and group cohesion is vital to group success and individual development. There is a lack, however, of information on the implementation and outcomes of specific types of team building activities. A majority of recent team building literature focuses on increasing and enhancing performance as opposed to the aforementioned affective outcomes (Klein et al., 2009).

Just as there are many differing definitions of SOC, there are many instruments used to measure it. The SCI is the most widely used and validated measure but has been criticized for not providing enough information about SOC. The CCS focuses specifically on the sense of classroom community and includes two subscales. The first describes the feeling of connectedness in the classroom and the second evaluates learning. Although the CCS was developed and tested in virtual classrooms, it is suitable for use in any learning environment, including traditional classrooms (Rovai, 2002). The following chapter discusses the methodology and instrument development used in the present study. 


\section{Chapter 3 Methodology}

This chapter describes the sample, the instrument selection, instrument adaptation and design, pilot study, procedures, and data analysis. The instrument and sample were selected to best address the purpose of the study, to determine whether students in classes whose instructors are intentional about creating a classroom community have a stronger sense of classroom community.

\section{Sample}

The sample was comprised of professors and undergraduate students at California Polytechnic State University, San Luis Obispo (Cal Poly) currently teaching or enrolled in major introductory courses. The courses were selected on the condition that they were a two or four-unit major introductory class and because they focused primarily on firstyear, first-time students just entering their chosen major. The courses were not necessarily content based but rather provided a way for new students to familiarize themselves with their classmates, the major, and the university in general. Each course was selected based on its description in the 2010-2011 course catalog. Although there are over 4,000 first time first year students and transfer students each year, only ten courses in the fall 2011 catalog met the criteria for data collection. Of these ten classes, data were collected from four. These four applicable courses were housed within three different colleges. One course was co-taught resulting in data for two professors. One class had two sections taught by the same professor. Census sampling was attempted For the population of 300, 113 questionnaires were administered and collected. All were considered usable with the exception of two students who did not produce enough 
responses to determine their sense of classroom community score or their student status.

71 of the 113 student responses were from first time, first year students.

\section{Instrument Selection}

There were two instruments used in this study. The first was a questionnaire completed by instructors (Appendix A) while the second was a questionnaire completed by students (Appendix C) In addition to new questions, the student questionnaire included the Classroom Community Scale (CCS) (Rovai, 2002). The CCS was selected to be a component of the student instrument due to its established reliability and validity in school and classroom settings. Although primarily tested in virtual learning communities, the CCS was intended for use across a variety of environments. The 20 -item CCS was short and did not require extra verbal instructions, making it easy to administer during the ten-minute time allotted for the questionnaire completion.

\section{Instrument Design}

An original instrument was designed and used to collect quantitative and qualitative data to reflect community building activities and student sense of classroom community. The instructor questionnaire was designed to be completed as an in-person or phone interview between the researcher and the instructor. The questions were designed to allow the instructor to answer truthfully about their focus on building classroom community and to provide details about any community building activities conducted in their classrooms. The instructor questionnaire was not tested for reliability or validity and was intended to serve as an exploratory tool.

The student questionnaire was designed in three parts. Part one corresponded with the instructor interview and asked students to describe any community building activities 
conducted in their classrooms. Students were also asked to indicate whether the activity was fun and effective in community building. Lastly, students provided information about the timing and duration of each activity. Students had the opportunity to describe up to five activities and were encouraged to include more if necessary. Part two of the student instrument was the aforementioned Classroom Community Scale (Rovai, 2002). The CCS was developed based on the review of relevant literature. The review revealed that, regardless of setting, there are several characteristics of sense of community. These characteristics include connectedness, cohesion, spirit, trust, and interdependence among members. In addition to these characteristics the CCS was created to specifically address classroom community. The initial version of the CSS included a pool of 40 items, these items were subsequently reviewed for relevance and salience. Half of the final list of 20 items was negatively worded while the other half was positively worded. The items were then reordered to avoid responses based on related items. 10 items on the final scale refer to feelings of connectedness and 10 items are related to, "the use of interaction within the community to construct understanding and the extent to which learning goals are being satisfied within the classroom setting" (Rovai, 2002, p. 202). Examples of each of these types of items are, "I feel that this course is a family" and "I feel that this course does not promote a desire to learn". The last steps in the instrument design process were measurements for reliability and validity. Although the CCS has been primarily utilized in virtual learning environments (i.e., Ritter et al., 2010; Arbaugh, 2010; Overbaugh \& Nickel, 2011), Rovai explains that the scale is applicable in multiple settings. The wording in the items of the CCS was not modified for the present study. The wording of the introductory paragraph was changed to specify that students respond based 
exclusively on their experience in their current major introductory class in the fall quarter of 2011. The third part of the student questionnaire included brief demographic questions. Students were asked to indicate items such as their year in school and whether they had previous relationships with other students or the instructor of the targeted class. The third section did not ask questions related to the students' background outside of the class to try to isolate the effects of the introductory course and any community building activities facilitated by the instructor.

\section{Pilot Study}

Prior to the administration of the questionnaire, a pilot study was administered in an introductory level course in the Recreation, Parks, and Tourism Administration Department (RPTA). RPTA 101, a course not applicable for the study, was chosen as the pilot population due to the small number of targeted classes. The pilot test was completed to ensure quality and clarity of the study instrument. The pilot study served to provide an accurate time frame in which to expect questionnaires to be completed. The wording of two items was adjusted to increase clarity.

\section{Human Subjects Review Procedures}

After the instruments were created, they were included in a submission to Dr. Steve Davis, the chair of the Cal Poly Human Subjects Committee. Research protocol was submitted which included the following materials: title of the research; the names and departments of the primary investigator and thesis committee; the statement of purpose and benefits; research methods including information on the subjects, researchers, materials, and procedures; an informed consent form for instructors and students. The research protocol was submitted for minimal review as there were no 
forecasted risks to participants. The project was accepted and was exempt from further review.

\section{Data Collection}

Following approval from the Human Subjects Committee as well as instructor consent, the questionnaire was administered to the five participating instructors and five participating class sections. Instructors were contacted via e-mail during the seventh and eight week of the fall quarter, 2011 to request their participation. Data collection took place primarily during the eighth and ninth weeks of the fall quarter. Data collection was a two-part process: Part one involved a short, in-person or phone interview between the instructor and a researcher. Instructor participation was voluntary and names will not be associated with course numbers. The instructor was read a thirty-second, verbal description of the research and a definition of "Sense of Community". The instructor was then asked up to three questions to describe the community building activities (if any) that took place in their targeted classroom. Including the researcher's introduction, the instructors' portion of the study took under five minutes and was completed outside of the class meeting time at the instructors' convenience. Part two of the process involved a self-administered pencil and paper questionnaire for the students in the participating classes. Students were also informed that their participation was voluntary and anonymous. The students were read a brief (one minute) explanation of the research and then had the opportunity to complete the questionnaire. The students' portion of the process took fewer than ten minutes. 


\section{Data Analysis}

Student and instructor responses were coded and entered into Microsoft Excel spreadsheets. Secondary data analysis for this study was performed using Minitab 16 statistical package. Activity descriptions were reviewed and sorted into 14 different categories. To ease legibility in the tables contained in chapter four, these activities are further sorted into "academic activities" and "social activities". The classroom community scores were derived from the second half of the instrument, the Classroom Community Scale designed by Rovai (2002). The overall sense of classroom community is a composite score of the connectedness subscale score and the learning subscale score. With two exceptions, each student's possible score falls within a range of $0-80$ with 80 being the highest sense of classroom community.

Descriptive statistics (tables 1-15) were created to display frequency and percentages of responses to all of the questions in the first and third parts of the student questionnaire as well as to compare these results to the mean sense of classroom community scores acquired in the second part of the student questionnaire. Chi-square tests and one-way analysis of variance (ANOVA) tests were used to gain further insight into the differences in classroom community scores between courses and instructor and student responses. 


\section{Chapter 4-Results}

This chapter outlines the descriptive statistics of the sample and addresses the research questions with secondary analysis.

The student $(\mathrm{n}=113)$ and instructor $(\mathrm{n}=5)$ characteristics and responses are outlined in the following tables (1-14). These characteristics include sense of classroom community; perception of instructor's intention to create classroom community; activity descriptions; new student status; number of students known prior to the course; time spent on each activity; activity enjoyment; and activity effectiveness. These tables report mean sense of classroom community scores as well as standard deviation, count, and percentage of responses.

\section{Participant Characteristics and Responses}

Table 1 shows the number of students per course. The Agriculture Education course was split into two sections. For the purposes of this project, both sections were considered as one class. The courses represent three colleges of the university: the College of Agriculture, Food and Environmental Science (Agricultural Education (Ag Ed)), the College of Liberal Arts (Child Development and History), and the College of Science and Mathematics (Statistics). 
Table 1

Respondents by Course

\begin{tabular}{llc}
\hline Course & $\mathrm{n}$ & $\%$ \\
\hline Child Development & 40 & 35.40 \\
Ag Ed & 30 & 26.55 \\
History & 22 & 19.47 \\
Statistics & 21 & 18.58 \\
Total & 113 & \\
\hline
\end{tabular}

\section{Sense of Classroom Community}

The students in the Ag Ed course had the highest mean sense of classroom community. A one-way ANOVA test comparing the first time, first year student sense of classroom community scores across courses provided a p-value of 0.00 indicating that at least one mean CCS differed from the others. A Tukey comparison showed that the mean CCS in the Ag Ed class was statistically higher than those of Child Development and History. For a complete presentation of these findings, see table 2. 
Table 2

Mean Sense of Classroom Community by Course

\begin{tabular}{lcll}
\hline Course & $\mathrm{n}$ & Mean & SD \\
\hline Ag Ed & 30 & $64.57^{\mathrm{a}}$ & 8.27 \\
Statistics & 21 & $61.81^{\mathrm{ab}}$ & 8.26 \\
Child Development & 40 & $56.08^{\mathrm{bc}}$ & 9.69 \\
& & & \\
History & $21^{*}$ & $53.81^{\mathrm{c}}$ & 5.40 \\
Total & $112^{*}$ & 58.96 & 9.24 \\
\hline
\end{tabular}

*One respondent did not provide enough responses to produce a Classroom Community Score.

a, b, c, d Values with different letters vary significantly at an alpha of .05.

A general linear model relating CCS to the number of other students previously known, course, number of activities reported, student status, and gender. Even when the model was adjusted for each of these five factors, course status remained the only factor with a significant effect on classroom community score ( $p$-value=.001).

\section{Intent to Create Classroom Community}

Each of the instructors responded that they did conduct activities intended to build community within their classrooms. When asked about the degree to which they felt they created a classroom environment in which students were connected to each other, two instructors answered 4 "quite a bit" and three instructors (one class was co-taught) answered 5, "to a great extent". A majority of students across the four courses perceived that their instructors intentionally created a classroom environment in which students were connected to each other. 
Table 3 exhibits the mean student perception of the instructor's intention to create classroom community by course. In a one-tailed test for two proportions, the proportion of students who perceived the instructor's intent as a 4 ("quite a bit") or 5 ("to a great extent") in the courses whose instructors indicated a score of $4(42 / 62)$ was compared to the proportion of students who perceived the instructor's intent as a 4 or 5 in the courses whose instructors indicated a score of $5(45 / 11)$. The test resulted in a p-value of 0.005 indicating that students' perception of the instructors' intent was consistent with the instructors' indicated intent.

Table 3

Mean Student Perception of Instructor's Intention to Create Classroom Community by Course

\begin{tabular}{lccc}
\hline Course & $\mathrm{n}$ & Mean & SD \\
\hline Statistics & 21 & 4.43 & 0.60 \\
Ag Ed & 30 & 4.13 & 0.68 \\
History & 22 & 3.86 & 0.64 \\
Child Development & 40 & 3.83 & 0.84 \\
Total & 113 & 4.03 & 0.75 \\
\hline
\end{tabular}




\section{Community Building Activities}

Each student described between one and five activities they felt were designed to create classroom community. These activities were sorted into sub-types (academic and social) and twelve different descriptive categories. As shown in table 4, the most commonly described academic activity was in-class group discussion (27\%), and the most commonly described social activity was name games $(10 \%)$. Instructors described a total of just nine different activities the most common of which were in-class group discussions and in-class group activities. One instructor described a social activity, Distributing contact information to students. 
Table 4

Student Activity Type by Course

\begin{tabular}{|c|c|c|c|c|c|c|c|c|c|c|}
\hline \multirow[b]{2}{*}{ Activity Type } & \multicolumn{2}{|c|}{ Ag Ed } & \multicolumn{3}{|c|}{ Child Development } & \multirow{2}{*}{$\begin{array}{c}\text { History } \\
\%\end{array}$} & \multicolumn{2}{|c|}{ Statistics } & \multicolumn{2}{|c|}{ Total } \\
\hline & $f$ & $\%$ & $f$ & $\%$ & $f$ & & $f$ & $\%$ & $f$ & $\%$ \\
\hline $\begin{array}{l}\text { Academic Activities } \\
\text { In-class Group } \\
\text { Discussion }\end{array}$ & 1 & 2 & 39 & 54 & 16 & 42 & 2 & 4 & 58 & 27 \\
\hline $\begin{array}{l}\text { Out of Class Group } \\
\text { Activity/Project }\end{array}$ & 6 & 11 & 5 & 7 & 13 & 34 & 16 & 31 & 40 & 19 \\
\hline $\begin{array}{l}\text { In-class Group } \\
\text { Activity/Project }\end{array}$ & 2 & 4 & 24 & 33 & 0 & 0 & 0 & 0 & 26 & 12 \\
\hline Presentation/Lesson & 16 & 30 & 0 & 0 & 2 & 5 & 0 & 0 & 18 & 8 \\
\hline $\begin{array}{l}\text { Circular/Inclusive } \\
\text { Classroom Set-Up }\end{array}$ & 2 & 4 & 0 & 0 & 1 & 3 & 2 & 4 & 5 & 2 \\
\hline Partner Work & 2 & 4 & 0 & 0 & 0 & 0 & 6 & 12 & 8 & 4 \\
\hline $\begin{array}{l}\text { Changing Seats/ } \\
\text { Groups }\end{array}$ & 2 & 4 & 0 & 0 & 0 & 0 & 0 & 0 & 2 & 1 \\
\hline $\begin{array}{l}\text { Presentation } \\
\text { Feedback }\end{array}$ & 1 & 2 & 0 & 0 & 0 & 0 & 0 & 0 & 1 & 0.5 \\
\hline Social Activities & & & & & & & & & & \\
\hline Name Game & 2 & 4 & 2 & 3 & 2 & 5 & 16 & 31 & 22 & 10 \\
\hline Nametags & 14 & 26 & 0 & 0 & 4 & 11 & 0 & 0 & 18 & 8 \\
\hline Self-Introduction & 6 & 11 & 0 & 0 & 0 & 0 & 3 & 0 & 9 & 4 \\
\hline Partner Introduction & 0 & 0 & 1 & 1 & 0 & 0 & 6 & 12 & 7 & 3 \\
\hline Peer Mentoring & 0 & 0 & 1 & 1 & 0 & 0 & 0 & 0 & 1 & 0.5 \\
\hline $\begin{array}{l}\text { Contact Info } \\
\text { Distribution }\end{array}$ & 0 & 0 & 0 & 0 & 0 & 0 & 0 & 0 & 0 & 0 \\
\hline Total & 54 & & 72 & & 38 & & 51 & & 215 & \\
\hline
\end{tabular}


Due to the widely varying number of students reporting each activity, statistically significant differences between the different activities and their associated Classroom Community Scale Scores (CCS) was unable to be computed. Table 5 represents each of the described activities and their associated CCS score. 
Table 5

Mean Sense of Classroom Community Score by Activity Type

\begin{tabular}{|c|c|c|c|c|}
\hline & $\mathrm{n}$ & Mean & SD & $\%$ \\
\hline $\begin{array}{l}\text { Academic Activities } \\
\text { In-class Group } \\
\text { Discussion }\end{array}$ & $57^{*}$ & 55.74 & 9.05 & 26.76 \\
\hline $\begin{array}{l}\text { Out of Class Group } \\
\text { Activity/Project }\end{array}$ & $39^{*}$ & 58.21 & 8.14 & 18.31 \\
\hline $\begin{array}{l}\text { In-class Group } \\
\text { Activity/Project }\end{array}$ & 26 & 57.38 & 10.42 & 12.21 \\
\hline Presentation/Lesson & 18 & 65.94 & 7.34 & 8.45 \\
\hline Partner Work & 8 & 61.29 & 9.79 & 3.76 \\
\hline $\begin{array}{l}\text { Circular/Inclusive } \\
\text { Classroom Set-Up }\end{array}$ & 5 & 62.20 & 5.36 & 2.35 \\
\hline $\begin{array}{l}\text { Changing Seats/ } \\
\text { Groups }\end{array}$ & 2 & 70.00 & 1.41 & 0.94 \\
\hline $\begin{array}{l}\text { Presentation } \\
\text { Feedback }\end{array}$ & 1 & 54.00 & 0.00 & 0.47 \\
\hline$\frac{\text { Social Activities }}{\text { Name Game }}$ & 22 & 61.09 & 7.00 & 10.33 \\
\hline Nametags & 18 & 63.50 & 8.11 & 8.45 \\
\hline Self-Introduction & 9 & 57.33 & 9.85 & 4.23 \\
\hline Partner Introduction & 7 & 64.29 & 5.94 & 3.29 \\
\hline Peer Mentoring & 1 & 60.00 & 0.00 & 0.47 \\
\hline $\begin{array}{l}\text { Contact Info } \\
\text { Distribution } \\
\text { Total }\end{array}$ & $213 *$ & 5958 & - & - \\
\hline
\end{tabular}




\section{Student Status}

Students were categorized in one of three groups first time, first year students;

transfer students new to Cal Poly; and returning Cal Poly students. The targeted group for this study was the first time, first year students $(n=71)$. This group represents $63 \%$ of respondents. These data are represented in table 6.

Table 6

Student Status by Course

\begin{tabular}{|c|c|c|c|c|c|c|c|c|c|c|}
\hline \multirow[b]{2}{*}{ Student Type } & \multicolumn{2}{|c|}{ Ag Ed } & \multicolumn{2}{|c|}{ Child Development } & \multicolumn{2}{|c|}{ History } & \multicolumn{2}{|c|}{ Statistics } & \multicolumn{2}{|c|}{ Total } \\
\hline & $f$ & $\%$ & $f$ & $\%$ & $f$ & $\%$ & $f$ & $\%$ & $f$ & $\%$ \\
\hline $\begin{array}{l}\text { First Time/ } \\
\text { First Year }\end{array}$ & 16 & 53 & 19 & 48 & 19 & 90 & 17 & 81 & 71 & 63 \\
\hline Returning & 9 & 30 & 12 & 30 & 1 & 5 & 1 & 5 & 23 & 21 \\
\hline Transfer & 5 & 17 & 9 & 23 & 1 & 5 & 3 & 14 & 17 & 15 \\
\hline Total & 30 & & 40 & & $21 *$ & & 21 & & 112 & \\
\hline
\end{tabular}

*One student did not indicate their student status.

Table 7 shows the mean sense of classroom community for each type of students.

There were no statistically significant differences in CCS scores between classes. 
Table 7

Mean Sense of Classroom Community Score by Student Status

\begin{tabular}{lcll}
\hline Student Status & $\mathrm{n}$ & Mean & SD \\
\hline First Time/ & 71 & $58.13^{*}$ & 9.08 \\
First Year & & & \\
Returning & 23 & 58.48 & 9.57 \\
Transfer & 17 & 64.61 & 8.60 \\
Total & $111^{\dagger}$ & 58.97 & 9.28 \\
\hline
\end{tabular}

*One respondent did not have enough responses to produce a Classroom Community Score.

${ }^{\dagger}$ One respondent did not provide their student status

\section{Number of Other Students Known Prior to the Class}

The majority of respondents (47\%) did not know any other students in their class prior to the start of the quarter studied. Table 8 shows the frequency and percentage of the different numbers of classmates each student knew prior to the start of the course. 
Table 8

Number of Other Students Known Prior to the Class by Course

\begin{tabular}{|c|c|c|c|c|c|c|c|c|c|c|}
\hline \multirow[b]{2}{*}{$\begin{array}{l}\text { Number of } \\
\text { Students Know1 }\end{array}$} & \multicolumn{2}{|c|}{ Ag Ed } & \multicolumn{2}{|c|}{ Child Development } & \multicolumn{2}{|c|}{ History } & \multicolumn{2}{|c|}{ Statistics } & \multicolumn{2}{|c|}{ Total } \\
\hline & $f$ & $\%$ & $f$ & $\%$ & $f$ & $\%$ & $f$ & $\%$ & $f$ & $\%$ \\
\hline 0 & 11 & 37 & 23 & 58 & 9 & 43 & 10 & 48 & 53 & 47 \\
\hline 1 & 8 & 27 & 7 & 18 & 6 & 29 & 1 & 5 & 22 & 19 \\
\hline 2 & 4 & 13 & 6 & 15 & 3 & 14 & 5 & 24 & 18 & 16 \\
\hline 3 & 3 & 10 & 2 & 5 & 2 & 10 & 2 & 10 & 9 & 8 \\
\hline $4-8$ & 4 & 13 & 2 & 5 & 1 & 5 & 3 & 15 & 10 & 10 \\
\hline Total & 30 & & 40 & & 21 & & 21 & & 113 & \\
\hline
\end{tabular}

Note. Due to rounding of numbers, percentages are less than $100 \%$.

Table 9 represents the mean sense of classroom community based on the number of other students known. The highest mean sense of classroom community corresponded to the students who knew five other students prior to the beginning of the course $(n=4)$. The difference between means the number of students known prior to the class was not statistically significant. 
Table 9

Mean Sense of Classroom Community Score by Number of Other Students Known Prior to the Class

\begin{tabular}{|c|c|c|c|}
\hline Number of Students Known & $\mathrm{n}$ & Mean & $\mathrm{SD}$ \\
\hline 0 & 53 & $58.40^{*}$ & 9.63 \\
\hline 1 & 22 & 57.41 & 9.40 \\
\hline 2 & 18 & 58.61 & 8.73 \\
\hline 3 & 9 & 59.78 & 6.44 \\
\hline 4 & 4 & 62.75 & 10.24 \\
\hline 5 & 4 & 66.75 & 9.46 \\
\hline 6 & 1 & 62.00 & 0.00 \\
\hline 7 & 0 & - & - \\
\hline 8 & 1 & 77.00 & 0.00 \\
\hline Total & 112 & 59.17 & 9.07 \\
\hline
\end{tabular}

*One respondent did not have enough responses to produce a Classroom Community Score.

\section{Time Spent on Activities}

Each student was asked to estimate the number of minutes spent on each activity conducted in their classrooms. A one-way ANOVA analysis of CCS scores compared 
length of activity for all respondents resulted in a statistically significant p-value of 0.046 but a Tukey comparison did not allow for further insight into which activity lengths make a significant difference in CCS scores. These findings are presented in table 10. 
Table 10

Mean Time in Minutes Spent on Each Activity by Course

\begin{tabular}{|c|c|c|c|c|c|c|c|c|c|c|c|}
\hline & \multicolumn{2}{|c|}{$\underline{A g E d}$} & \multicolumn{2}{|c|}{ Child Development } & \multicolumn{2}{|c|}{ it History } & \multicolumn{2}{|c|}{ Statistics } & \multicolumn{3}{|c|}{ Total } \\
\hline Activity Type & Mean & $\mathrm{SD}$ & Mean & $\mathrm{SD}$ & Mean & $\mathrm{SD}$ & Mean & $\mathrm{SD}$ & $\mathrm{n}$ & Mean & SD \\
\hline Academic Activity & & & & & & & & & & & \\
\hline $\begin{array}{l}\text { In-class Group } \\
\text { Discussion }\end{array}$ & 120 & 0 & - & - & 31 & 14 & 23 & 11 & $57 *$ & 48 & 27 \\
\hline $\begin{array}{l}\text { Out of Class Group } \\
\text { Activity/Project }\end{array}$ & p 141 & 71 & 50 & 23 & 104 & 58 & 68 & 20 & $39 *$ & 93 & 52 \\
\hline $\begin{array}{l}\text { In-class Group } \\
\text { Activity/Project }\end{array}$ & 105 & 106 & 53 & 27 & - & - & - & - & 26 & 46 & 34 \\
\hline Presentation/Lesson & n 5 & 0 & 90 & 42 & 38 & 32 & - & - & 18 & 9 & 13 \\
\hline Partner Work & 38 & 32 & - & - & - & - & 30 & 16 & 8 & 32 & 19 \\
\hline $\begin{array}{l}\text { Circular/Inclusive } \\
\text { Classroom Set-Up }\end{array}$ & 60 & 0 & - & - & 60 & 0 & 60 & 0 & 5 & 60 & 0 \\
\hline $\begin{array}{l}\text { Changing Seats/ } \\
\text { Groups }\end{array}$ & 5 & 0 & - & - & - & - & - & - & 2 & 5 & 0 \\
\hline $\begin{array}{l}\text { Presentation } \\
\text { Feedback }\end{array}$ & 5 & 0 & - & - & - & - & - & - & 1 & 5 & 0 \\
\hline Social Activities & & & & & & & & & & & \\
\hline$\overline{\text { Peer Mentoring }}$ & - & - & 120 & 0 & - & - & - & - & 1 & 120 & 0 \\
\hline Partner Introduction & $n-$ & - & 60 & 0 & - & - & 24 & 7 & 7 & 29 & 15 \\
\hline Name Game & 8 & 4 & 30 & 0 & 5 & 0 & 24 & 15 & 22 & 22 & 15 \\
\hline Self-Introduction & 25 & 8 & - & - & - & - & 13 & 8 & 9 & 21 & 10 \\
\hline Nametags & 14 & 16 & - & - & 39 & 27 & - & - & 18 & 19 & 21 \\
\hline $\begin{array}{l}\text { Contact Info } \\
\text { Distribution }\end{array}$ & - & - & - & - & - & - & - & - & - & - & - \\
\hline
\end{tabular}




\section{Activity Enjoyment}

Students were asked to report whether or not each of their described activities was fun. Due to varying numbers of students reporting each activity, statistical significance between activity types was unable to be computed. The most enjoyable academic activity was working with partners (100\% enjoyable) and the most enjoyable social activity was self-introduction (100\%) enjoyable. The findings in table 11 are presented in order of number of times they were reported. 
Table 11

Activity Enjoyment by Activity Type

\begin{tabular}{|c|c|c|c|}
\hline \multirow[b]{2}{*}{ Activity Type } & \multicolumn{2}{|c|}{ Enjoyable } & \multirow[t]{2}{*}{ Total } \\
\hline & $f$ & $\%$ & \\
\hline $\begin{array}{l}\text { Academic Activities } \\
\text { In-class Group } \\
\text { Discussion }\end{array}$ & 49 & 84 & 58 \\
\hline $\begin{array}{l}\text { Out of Class Group } \\
\text { Activity/Project }\end{array}$ & 33 & 83 & 40 \\
\hline $\begin{array}{l}\text { In-class Group } \\
\text { Activity/Project }\end{array}$ & 25 & 96 & 26 \\
\hline Presentation/Lesson & 16 & 94 & 17 \\
\hline $\begin{array}{l}\text { Circular/Inclusive } \\
\text { Classroom Set-Up }\end{array}$ & 4 & 80 & 5 \\
\hline $\begin{array}{l}\text { Changing Seats/ } \\
\text { Groups }\end{array}$ & 2 & 67 & 3 \\
\hline $\begin{array}{l}\text { Presentation } \\
\text { Feedback }\end{array}$ & 1 & 100 & 1 \\
\hline Social Activities & & & \\
\hline Name Game & 21 & 95 & 22 \\
\hline Nametags & 17 & 94 & 18 \\
\hline Self-Introduction & 9 & 100 & 9 \\
\hline Partner Introduction & 2 & 100 & 2 \\
\hline Peer Mentoring & 1 & 100 & 1 \\
\hline Contact Info & 0 & 0 & 0 \\
\hline & $f$ & $\%$ & \\
\hline Total & 192 & 89 & 215 \\
\hline
\end{tabular}

Note. Due to rounding of numbers, percentages are less than $100 \%$. 


\section{Timing in Quarter of Each Activity}

Students were asked to determine when in the quarter each activity took place.

Table 12 provides counts and percentages of the timing of each activity. 
Table 12

Activity Type by Timing in Quarter

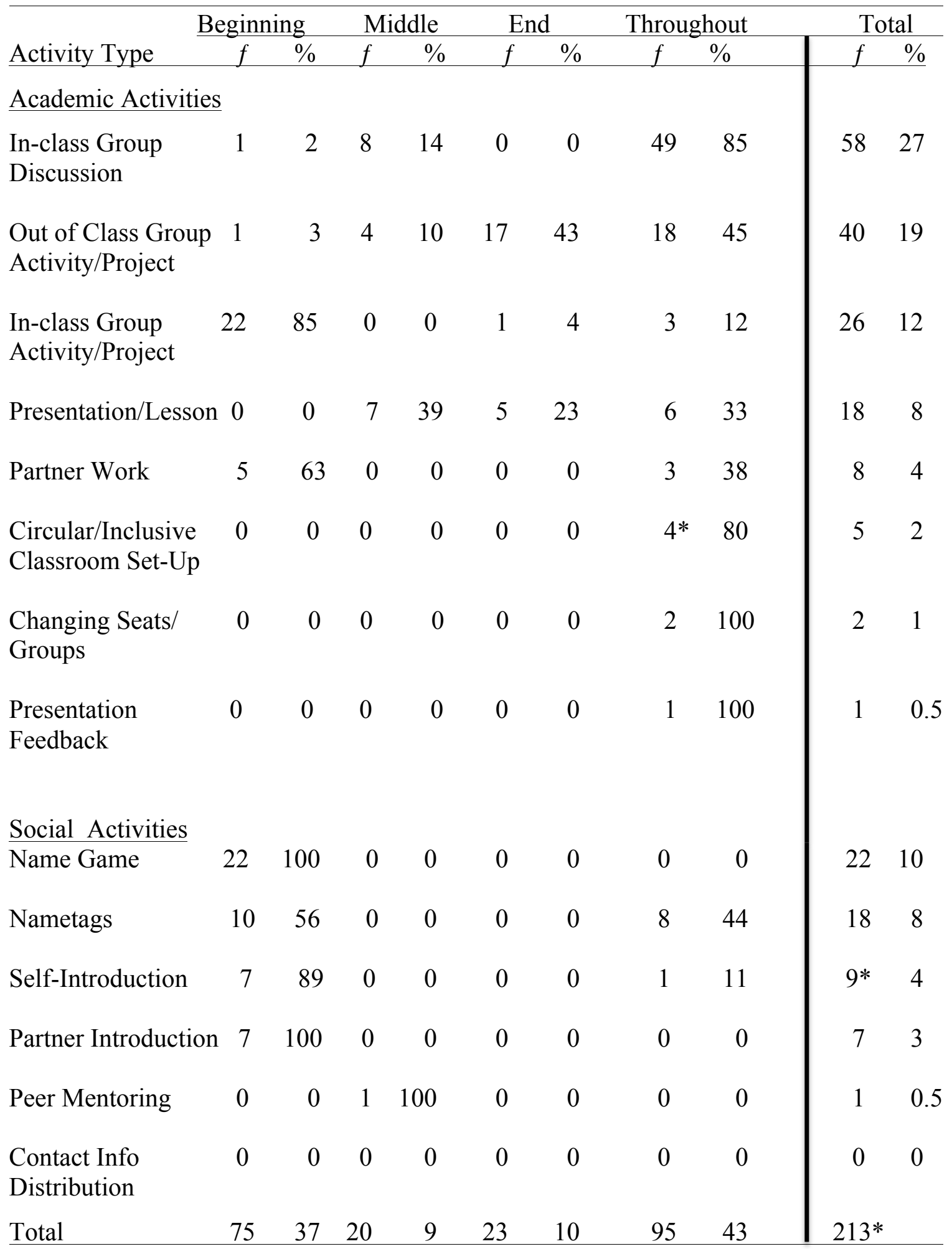

*Two students did not provide the timing in the quarter of their activity. 
Table 13 shows the number of activities in each time category by course. A chisquare test for differences in the distribution of activities throughout the quarter across the four classes revealed a p-value of 0.00 indicating that there is no discernable pattern to the distribution of the activities throughout the quarter across the classes.

Table 13

Timing in Quarter by Course

\begin{tabular}{lcccccccc|rr}
\hline & \multicolumn{2}{c}{ Beginning } & \multicolumn{2}{c}{ Middle } & \multicolumn{2}{c}{ End } & \multicolumn{2}{c}{ Throughout } & \multicolumn{2}{c}{ Total } \\
\cline { 2 - 11 } & $f$ & $\%$ & $f$ & $\%$ & $f$ & $\%$ & $f$ & $\%$ & \multicolumn{2}{c}{$\%$} \\
\hline Ag Ed & 17 & 31 & 9 & 17 & 7 & 13 & 20 & 37 & 54 & 25 \\
Child & & & & & & & & & & \\
Development & 27 & 38 & 11 & 15 & 2 & 3 & 32 & 44 & 72 & 33 \\
Statistics & 27 & 53 & 0 & 0 & 0 & 0 & 24 & 47 & 51 & 24 \\
History & 4 & 11 & 0 & 0 & 14 & 37 & 19 & 53 & 37 & 18 \\
Total & & & & & & & & & $213 *$ & \\
\hline
\end{tabular}

*Two students did not indicate the timing in the quarter of their activity.

\section{Perceived Effectiveness of Activities}

Table 14 shows the frequency and percentage results from the Likert scale of students' perceived effectiveness of each activity. It also provides an iteration of the corresponding mean sense of community score. Due to the varying sample sizes of each 
activity, statistical significance of effectiveness between activities was not computed. The findings are presented in order of frequency. 
Table 14

Average Perceived Effectiveness (PE) and Mean Sense of Classroom Community (SCC) by Activity Type

\begin{tabular}{|c|c|c|c|c|c|}
\hline Activity Type & $\underline{\mathrm{n}}$ & $\begin{array}{l}\text { Mean } \\
\text { PE }\end{array}$ & SD & $\begin{array}{r}\text { Mean } \\
\text { SCC }\end{array}$ & $\mathrm{SD}$ \\
\hline Academic Activities & & & & & \\
\hline $\begin{array}{l}\text { In-class Group } \\
\text { Discussion }\end{array}$ & 58 & 3.65 & 0.86 & 55.73 & 9.05 \\
\hline $\begin{array}{l}\text { Out of Class Group } \\
\text { Activity/Project }\end{array}$ & 40 & 3.88 & 0.72 & 58.21 & 8.14 \\
\hline $\begin{array}{l}\text { In-class Group } \\
\text { Activity/Project }\end{array}$ & 26 & 3.65 & 0.89 & 57.38 & 10.42 \\
\hline Presentation/Lesson & 18 & 4.17 & 0.62 & 65.94 & 7.33 \\
\hline Partner Work & 8 & 3.88 & 0.35 & 61.25 & 9.07 \\
\hline $\begin{array}{l}\text { Circular/Inclusive } \\
\text { Classroom Set-Up }\end{array}$ & $4^{*}$ & 3.80 & 1.10 & 60.25 & 3.59 \\
\hline $\begin{array}{l}\text { Changing Seats/ } \\
\text { Groups }\end{array}$ & 2 & 4.50 & 0.71 & 70.00 & 1.40 \\
\hline $\begin{array}{l}\text { Presentation } \\
\text { Feedback }\end{array}$ & 1 & 4.00 & 0.00 & 54.00 & 0.00 \\
\hline Social Activities & & & & & \\
\hline Name Game & 22 & 3.68 & 0.89 & 61.09 & 7.00 \\
\hline Nametags & 18 & 3.67 & 0.84 & 63.50 & 8.11 \\
\hline Self-Introduction & 9 & 3.33 & 0.71 & 57.33 & 9.85 \\
\hline Partner Introduction & 7 & 4.14 & 0.90 & 64.29 & 5.94 \\
\hline Peer Mentoring & 1 & 5.00 & 0.00 & 60.00 & 0.00 \\
\hline $\begin{array}{l}\text { Contact Info } \\
\text { Distribution }\end{array}$ & - & - & - & - & - \\
\hline Total & 214 & & & & \\
\hline
\end{tabular}

Note. Due to rounding of numbers, percentages are less than $100 \%$. 


\section{Summary}

The results found in the primary analysis show that instructor intention to create classroom community is perceived by the students. Analysis also shows that which course the students were in had the largest impact on their classroom community scale scores. The following chapter will summarize and further discuss these results and will provide recommendations for future research. 


\section{Chapter 5-Discussion}

The purpose of this study was to determine whether an instructor's intentional effort to build community in their classroom resulted in a higher sense of classroom community among students. This study also examined what types of community building activities were conducted by each instructor and measured the students' responses to each different activity. This was intended to establish a preliminary set of best practices for creating classroom community. The following chapter summarizes the key literature, methodology, data analysis, and results of the study. A discussion of the significant findings is followed by practical and theoretical implications for this study and recommendations for future research.

\section{Summary of Background and Literature}

A strong sense of community in the school setting is credited with a number of positive outcomes for students including increased retention (i.e., Pervin, Reik, \& Dalrymple, 1966), academic achievement (i.e., Sherblom, Marshall, \& Sherblom, 2005), psychological development (i.e., Prezza \& Costantini, 1998), and decrease s in negative behavior (i.e., Battistich \& Hom, 1997). A number of educational and political initiatives such as the No Child Left Behind Act (2001) have highlighted the national interest in addressing retention rates and school performance. Despite the evidence that sense of community is linked to these educational concerns, a standardized definition of school and classroom community and how to achieve these ideals eludes researchers.

Cal Poly administration works hard to help first time, first year students integrate into the campus community and return after their first year through mentoring and 
orientation programs such as SOAR and "Week of Welcome." Some departments have also instituted mandatory introductory courses to acclimate students to their academic cohort and their specific major.

Sense of community theory is rooted in the field of community psychology and many researchers studying sense of community utilize McMillan and Chavis (1986) Sense of Community theory and the related Sense of Community Index. Research exists on different types of communities ranging from neighborhoods to classrooms (i.e., Prezza \& Costantini; Rovai, 2002). Although sense of community has been studied among elementary and secondary students and in extra curricular settings in colleges and universities (Berger, 1997), there is a limited amount of research on sense of classroom community in higher education. Recently, classroom community research has focused on investigating community in virtual learning environments as opposed to the traditional classroom (Overbaugh \& Nickel, 2011). The present study aimed to categorize and understand the effectiveness of the activities instructors use in their classrooms to help create relationships between students.

\section{Summary of Methodology}

This study targeted four two or four unit major introductory courses at Cal Poly. The four courses were representative of three different colleges within the university and were chosen because they focus on first time first year students entering their chosen major. 113 students were administered a questionnaire consisting of three parts: (1) questions regarding community building activities, (2) the Classroom Community Scale questionnaire, originally developed by Rovai (2002), and (3) demographic information. The five instructors (one course was co-taught) were interviewed separately and asked to 
describe the community building activities they use in their classrooms. All of the responses were usable.

\section{Summary of Results}

The results of this study indicated that course had the greatest effect on first time, first year students' sense of classroom community (CCS). Primary analysis showed that the most frequently reported activities were in-class group discussions and out of class group activities or projects. The activities that were most enjoyable included working with partners and self-introductions. While students reported thirteen different activities, instructors only reported four different activities. None of the activities that the students reported as most effective and most enjoyable were reported by instructors. All of the instructors indicated that they do conduct some community building activities and a test for two proportions showed that student perceptions of professors' intention to create a classroom environment in which students are connected to each other was consistent with the professor self-ratings.

One-way ANOVA at $\alpha=.05$ and a Tukey comparison were used to find significant differences among courses. Students in the Ag Ed course had a mean CCS score of 64.57 , which was indiscernible from Statistics $(\bar{x}=61.81)$ but was significantly higher than that of Child Development $(\bar{x}=56.08)$ and History $(\bar{x}=53.81)$. Other factors such as student status, gender, the number of activities reported, and the number of other students known prior to starting the class had a significant effect on sense of classroom community. 


\section{Discussion}

One of the most noteworthy findings of this study was the significance of the instructors' intention to create classroom community. The professors who reported that they, "to a great extent" created a classroom environment in which students were connected to each other were associated with students who agreed that the professor's intent was higher. The students in these courses also had higher classroom community scores than the students in courses whose professors reported that they created a classroom environment in which students were connected to each other "quite a bit". Although the professors did not have a set framework to follow as in Benefits-Based Programming (Allen, Stevens, Hurtes, and Harwell, 1998), the fact that professor intentionality was both recognized by students and resulted in higher sense of classroom community scores indicates the importance of instructor's role and is consistent with the analysis of Ritter et al. (2010) and Libbey (2004).

Students were asked to report the timing in the quarter of each of their reported activities. Students reported that all of the instructors conducted a majority of their activities throughout the quarter while only two courses reported activities being conducted in the middle of the quarter. A chi-square test was performed on these results and determined no uniformity in timing across courses. One contributor to this inconsistency could be the large number of activities throughout the quarter in comparison to the total number of activities in the history class. This is not the only factor as a chi-square test excluding the history class still resulted in a p-value of 0.00 Tinto’s (1975) Student Integration Model (SIM) uses analysis of social and academic environments to understand a student's decision to drop out of higher 
education. The model examines students' extra-curricular demographic variables to better understand their social integration into the school setting. In contrast to Tinto's findings, this study revealed that the only variable considered that had an effect on students' sense of classroom community was what course they were in. According to the general linear model relating the demographic and activity-specific variables including number of other students known, and student status (first time, first year; new to Cal Poly; or returning to Cal Poly), did not have significant effects on sense of classroom community. Although there is a body of empirical research about sense of community in educational settings, this research frequently focuses on communities built outside of the classroom (i.e., Berger, 1997). This study is unique in that it does not reference student background, extra-curricular activities, or living situations.

Rovai's (2002) original validation of the Classroom Community Scale, found that there was a significant difference in CCS scores between genders. In the present study, there was not a significant difference between genders. This could be because there were more females $(n=78)$ than males $(n=34)$ in this study, and the largest class, Child Development $(n=40)$ had only two males.

The classes that participated in this study were not necessarily reflective of all classes for first time, first year students at Cal Poly. Since these courses were designed to introduce new students to their majors, the sense of classroom community scores may not be representative of the rest of the population. Despite the fact that the sample is limited in size and scope, the findings are meaningful and consistent with previous sense of community theories and research. 
Limitations. This study was limited to instructors and students in two or four unit introductory classes. Only ten departments throughout the university offer applicable courses. These courses are designed to orient new students to their chosen major, indicating that these courses might not be representative of others at the university in terms of intentional community building.

In order to study community building activities conducted throughout the first quarter of the school year, data were collected in the last week of the quarter. This limited the study to instructors who were available to volunteer their courses. A number of courses were excluded due to time constraints.

Although the Classroom Community Scale was tested for reliability and validity, the instructor questionnaire and the student activity description questionnaire were not. The instrument was used in one pilot study prior to data collection. Additionally, students provided their own descriptions of activities as opposed to selecting activities from a predetermined list. While this allowed students to indicate exactly what happened in their classrooms, data coding relied on the researcher's interpretation. Additionally, all of the data were self-reported and therefore only as accurate as instructor and student responses.

\section{Conclusions}

The findings from this study lead to the following conclusions based on the research questions:

1. All instructors reported intentionally designing activities to build communities in their classrooms.

2. Students whose instructors felt they created classroom community "to a great extent" reported that they perceived their instructor's intent as higher than the 
students whose instructors felt they created classroom community "quite a bit". Students whose instructors felt they created classroom community "to a great extent" also reported higher classroom community scores than students whose instructors felt they created classroom community "quite a bit".

3. Partner or group activities resulted in higher sense of classroom community scores. Due to widely varying numbers of students reporting each activity, statistic significance between activities was unable to be computed.

4. Course was the major determining factor contributing to classroom community score.

\section{Recommendations}

Practical and theoretical implications. Based on the results of this study there are several practical and theoretical implications for creating community in face-to-face college classrooms. First, since students' perception of the instructors' intention to create classroom community was consistent with instructors' reported intent, instructors who wish to create classroom community should intentionally design their curriculum to this end.

Only ten courses across the entire university were applicable for this study. Five of these courses are housed in the College of Agriculture, Food, and Environmental Science (CAFES), two are in the College of Liberal Arts (CLA), two are in the College of Science and Mathematics, and one is in the College of Architecture \& Environmental Design. Neither the College of Business nor the College of Engineering provide an introductory course for any majors. Providing an introductory class for each major or college could provide a more consistent experience for all first year, first time students. 
The comparisons between disciplines illuminated differences in the community building practices of faculty in different colleges at Cal Poly, perhaps helping to explain varying retention rates. The effort being made by CAFES is evident through CCS scores in this study as

the course from CAFES had the highest mean CCS scores while the two classes in the College of Liberal Studies had the lowest.

In terms of activity design, the most frequently reported academic activities were in-class group activities and out of class group activities or projects. The most frequently reported social activities were name games and making nametags. Preliminary analysis shows that the activities that were the most enjoyable, and resulted in the highest CCS scores were group activities such as partner introduction and changing groups for projects. These findings, however, were based on limited sample sizes. Despite the undetermined significance, instructors looking to build classroom community should consider making group and partner experiences a priority. Future research will help determine best activities and practices to create the strongest bond between students.

Recent sense of school community research has passed over traditional college classrooms to focus on distance learning or elementary and secondary school-aged students. The results of this study, coupled with other studies on college student success and retention (i.e., Berger; Tinto), could help researchers gain a better understanding of the total experience for first year, first time students.

Future research. This study was intended to be a preliminary investigation of the types of activities that enhance sense of classroom community. Future research recommendations include using a wider cross section of students and courses. Using 
introductory courses from several different disciplines including courses not necessarily intended to help acclimate new students would provide a more realistic view of the actual effort and activities being conducted in college classrooms.

This study looked at only one academic quarter of instruction. Future research could benefit from using a longitudinal model to understand the effect of first year, first time student community building experiences on long-term benefits such as retention and academic success. On a smaller scale, asking students their expected grade in the targeted course, and their intent to return could provide a basis for a comparison of sense of classroom community and academic achievement or retention.

Additionally, this study essentially disregarded the personal characteristics of each student, ignoring many of the other factors that could affect individuals' sense of classroom community. Researching areas such as student backgrounds, extracurricular activities, and living situation could help narrow down the role of intentional classroom community building exercises on sense of classroom community.

A more developed instrument would help better define the different activity types. Exploring the details of each activity and understanding the differences between academic or content related activities and social activities could help clarify student preferences and help in the application of this research to other settings. Analyzing which activities are the most enjoyable and the most effective could provide instructors a roadmap for the best activities to use in their classrooms.

By exploring the types of activities that instructors conducted as well as the students' response, this study aimed to provide some insight into the activities that are the most enjoyable and successful in building community. Though small, this study paved 
the way for a larger, university-wide study to establish best practices for classroom community building in first year classes. By exploring the communities built in this study's targeted classrooms, the results also may make a case for establishing introductory courses for the many majors that currently do not have one. The results will have implications to help not only Cal Poly administration, but anyone interested in building community, in or out of the classroom. 


\section{References}

Agazarian, Y. (2001). A systems-centered approach to inpatient group psychotherapy. London: Jessica Kingsley Publishers.

Allen, L. R., Stevens, B., Hurtes, K., \& Harwell, R. (1998) Benefits-based programming of recreation services training manual. Ashburn, VA: National Recreation and Park Association. Retrieved from http://www.nrpa.org/jlr/

Arbaugh, J. B. (2010). Do undergraduates and MBAs differ online?: Initial conclusions from the literature. Journal of Leadership and Organizational Studies, 17 (2), 129-142. Retrieved from http://jlo.sagepub.com/

Arhar, J. M., \& Kromrey, J. D. (1993). Interdisciplinary teaming in the middle level school: Creating a sense of belonging for at-risk middle level students. Paper presented at the Annual Meeting of the American Educational Research Association, Atlanta. Retrieved from http://www.aera.net/

Astin, A. W. (1984). Student involvement: A developmental theory for higher education. Journal of College Student Development, 25 (4), 297-308. Retrieved from http://www.jcsdonline.org/

Baltes, P. B. (1997). On the incomplete architecture of human ontology: Selection, optimization, and compensation as foundation of develop- mental theory. American Psychologist, 23, 366-380. Retrieved from http://www.apa.org/pubs/journals/amp/index.aspx

Barber, B. L., Eccles, J. S., \& Stone, M. R. (2001). Whatever happened to the jock, the brain, and the princess? Young adult pathways linked to adolescent activity involvement and social identity. Journal of Adolescent Research, 16 (5), 429-455. Retrieved from http://jar.sagepub.com/

Battistich, V., Solomon, D., Kim, D., Watson, M., \& Schapps, E. (1995). Schools as communities, poverty levels of student populations and students' attitudes, motives and performance: A multilevel analysis. American Educational Research Journal, 32 (3), 627-658. Retrieved from http://www.aera.net/Publications/Journals/AmericanEducationalResearchJournal/t abid/12607/Default.aspx

Battistich, V., \& Hom, A. (1997). The relationship between students' sense of their school asa community and their involvement in problem behaviors. American Journal of Public Health, 87 (12), 1997-2001. Retrieved from http://ajph.aphapublications.org/

Baumeister, R. F., \& Leary, M. R. (1995). The need to belong: Desire for interpersonal attachments as a fundamental human motivation. Psychological Bulletin, 117 (3), 497-529. Retrieved from http://www.apa.org/pubs/journals/bul/index.aspx 
Berger, J. B. (1997). Students' sense of community in residence halls, social integration and first-year persistence. Journal of College Student Development, 38 (5), 441452. Retrieved from http://www.jcsdonline.org/

Birx, E., Lasala, K. B., \& Wagstaff, M. (2011). Evaluation of a team-building retreat to promote nursing faculty cohesion and job satisfaction. Journal of Professional Nursing, 27 (3), 174-178. Retrieved from http://www.professionalnursing.org/

Bloom, G. A., Loughead, T. M., \& Newin, J. (2008). Team building for youth sport. Journal of Physical Education, Recreation, and Dance, 79 (9), 44-47. Retrieved from http://www.aahperd.org/publications/journals/joperd/

Brown, R., \& Evans, W. P. (2002). Extracurricular activity and ethnicity: Creating greater school connection among diverse student populations. Urban Education, 37 (1), 41-58. Retrieved from http://uex.sagepub.com/

Bruner, M. W., \& Spink, K. S. (2011). Effects of team building on exercise adherence and group task satisfaction in a youth activity setting. Group Dynamics: Theory, Research, and Practice, 15 (2), 161-172. Retrieved from http://www.apa.org/journals/gdn/

Bryk, A. S., \& Driscoll, M. (1998). The high school as community: Contextual influence and consequences for students and teachers. Madison, WI: National Center on Effective Secondary Schools. Retrieved from http://www.ncset.org/publications/default.asp

Buller, P. F. (1986). The team building-task performance relation: Some conceptual and methodological refinements. Group and Organization Studies, 11 (3), 147-168. Retrieved from http://www.deepdyve.com/browse/journals/group-andorganization-studies

Busseri, M. A., Rose-Krasnor, L., Willoughby, T., \& Chalmers, H. (2006). A longitudinal examination of breadth and intensity of youth activity involvement and successful development. Developmental Psychology, 42 (6), 1313-1326. Retrieved from http://www.apa.org/pubs/journals/dev/index.aspx

Carron, A. V., Widmeyer, W. N., \& Brawley, L. R. (1988). Group cohesion and individual adherence to physical activity. Journal of Sport \& Exercise Psychology, 10 (2), 127-138. Retrieved from http://journals.humankinetics.com/jsep

Cartwright, D., \& Zander, A. F. (1968). Group dynamics: Research and theory. New York: Harper \& Row. 
Casey-Campbell, M., \& Martens, M. L. (2008). Sticking it all together: A critical assessment of the group cohesion-performance literature. International Journal of Management Reviews, 11 (2), 223-246. Retrieved from http://www.bam.ac.uk/bam-journals

Chavis, D. M., Hogge, J. H., McMillan, D. W., \& Wandersman, A. (1986). Sense of Community through Brunswick Lens: A first look. Journal of Community Psychology, 14(1), 24-40. Retrieved from http://www.scra27.org/publications

Chawla L. (1992). Childhood place attachments. In: Altman I., Low S. M., editors. Place Attachment. New York: Plenum Press. p. 63-86

Chipuer, H. M., \& Pretty, G. M. H. (1999). A review of the sense of community index: Current uses, factor structure, reliability, and further development. Journal of Community Psychology, 27 (6), 643-658. Retrieved from http://www.scra27.org/publications

Connell, J. P., \& Wellborn, J. G. (1991). Competence, autonomy, and relatedness: A motivational analysis of self-system processes. Minnesota symposia on child psychology, 23, 43-77. Retrieved from http://www.cehd.umn.edu/icd/mnsymposium/

Cropanzano, R., Byrne, Z. S., Bobocel, D. R., \& Rupp, D. E. (2001). Moral virtues, fairness heuristics, social entities, and other denizens of organizational justice. Journal of Vocational Behavior, 58 (2), 164-209. Retrieved from http://www.journals.elsevier.com/journal-of-vocational-behavior/

Cuba, L., \& Hummon, D. M. (1993). A place to call home: Identification with dwelling, community and region. Sociological Quarterly, 34 (1), 111-131. Retrieved from http://www.themss.org/publications.html

Davidson, W. B., \& Cotter, P. R. (1991). The relationship between Sense of Community and subjective well-being: A first look. Journal of Community Psychology, 19 (3). 246-253. Retrieved from http://www.scra27.org/publications

Deci, E. L., Vallerand, R. J., Pelletier, L. G., \& Ryan, R. M. (1991). Motivation and education: The self-determination perspective. Educational Psychologist, 26 (3), 325-346. Retrieved from http://www.apa.org/about/division/div15.aspx

Dewey, J. (1958). Experience and nature. Mineola, New York: Dover Publications, Inc.

Dick, W., Carey, L., \& Carey, J. O. (2005). The systematic design of instruction. $6^{\text {th }}$ Ed. New York: Longman. 
Dion, K. L. (2001). Group cohesion: From "field of forces" to multidimensional construct. Group Dynamics-Theory, Research, and Practice, 5 (1), 7-26. Retrieved from http://www.apa.org/pubs/journals/gdn/index.aspx

Dougherty, K., Natow, R., Bork, R. H., Jones, S., \& Vega, B. (2011). The politics of performance funding in eight states: Origins, demise, and change. Teachers College Record, 115 (1). Retrieved from http://ccrc.tc.columbia.edu/Collection.asp?cid=9

Durkheim, E. (1951). Suicide: A study in sociology. New York: Free Press.

Eccles, J. S., Early, D., Frasier, K., Belansky, E., \& McCarthy, K. (1997). The relation of connection, regulation, and support for autonomy to adolescents' functioning. Journal of Adolescent Research, 12 (2), 263-286. Retrieved from http://jar.sagepub.com/

Evans, S. D. (2007). Youth sense of community: Voice and power in community contexts. Journal of Community Psychology, 35 (6), 693-709. Retrieved from http://www.scra27.org/publications

Fried, M. (1982). Residential attachment: Sources of residential and community satisfaction. Journal of Social Issues, 38 (3), 107-119. Retrieved from http://www.spssi.org/index

Friedkin, N. E. (2004). Social Cohesion. Annual Review of Sociology, 30, 309-425.

Glynn, T. J. (1981). Psychological sense of community: Measurement and application. Human Relations, 34 (9), 789-818. Retrieved from

http://www.tavinstitute.org/humanrelations/about_journal/aims.html

Goodenow, C. (1993). The psychological sense of school membership among adolescents: scale development and educational correlates. Psychology in the Schools. 30 (1), 79-90. Retrieved from

http://onlinelibrary.wiley.com/journal/10.1002/(ISSN)1520-6807

Goodman, B. (2011). Common Data Set 2010-2011, Cal Poly State University, San Luis Obispo. Retrieved from http://www.ipa.calpoly.edu/publications_reports/cds/index.html

Greffrath, G., Meyer, C. D., \& Monyeki, A. (2008). The difference between a wilderness expedition and a centre-based team building program with regard to personal effectiveness. South African Journal for Research in Sport, Physical Education and Recreation, 30 (2), 53-69. Retrieved from http://academic.sun.ac.za/sajrsper/home.htm 
Gusfield, J. R. (1975). The community: A critical response. New York: Harper \& Row.

Hansen, D. M., Larson, R. W., \& Dworkin, J. B. (2003). What adolescents learn in organized youth activities: A survey of self-reported developmental experiences. Journal of Research on Adolescence, 13 (1), 25-55. Retrieved from http://jar.sagepub.com/

Hargreaves, A., Earl, L., \& Ryan, J. (1996). Schooling for change: Reinventing education for early adolescents. Bristol, PA: Falmer Press, Taylor \& Francis Inc.

Henry, K. L., Stanley, L. R., Edwards, R. W., Harkabus, L. C., \& Chapin, L. A. (2009). Individual and contextual effects of school adjustment on adolescent alcohol use. Prevention Science, 10 (3), 236-247. Retrieved from http://www.preventionresearch.org/prevscience.php

Institute of Education Sciences. (2009). Beginning postsecondary students longitudinal survey. Retrieved from http://nces.ed.gov/surveys/bps/.

Israel, G. D., Lionel, J. B., Beaulieu, \& Hartless, G. (2001). The influence of family and community capital on educational achievement. Rural Sociology, 66 (1), 43-68. Retrieved from http://www.ruralsociology.org/?page_id=106

Klein, C., DiazGranados, D., Salas, E., Le, H., Burke, C. S., Lyons, R., \& Goodwin, G. F. (2009). Does team building work? Small Group Research, 40 (2), 181-222.

Retrieved from http://sgrjournal.blogspot.com/

Kohut, H. (1984). How does analysis cure? Chicago: University of Chicago Press.

Johnson, D. R., Soldner, M., Leonard, J. B., Alvarez, P., Inkelas, K. K., Rowan-Kenyon, H., \& Longerbeam, S. (2007). Examining sense of belonging among first-year undergraduates from different racial/ethnic groups. Journal of College Student Development, 48 (5), 525-542. Retrieved from http://www.jcsdonline.org/

Lee, R. M., \& Robbins, S. B. (1995). Measuring belongingness: The social connectedness and the social assurance scales. Journal of Counseling Psychology, 42 (2), 232241. Retrieved from http://www.apa.org/pubs/journals/cou/index.aspx

Libbey, H. P. (2004). Measuring student relationships to school: Attachment, bonding, connectedness, and engagement. Journal of School Health, 74 (7), 274-283. Retrieved from http://www.ashaweb.org/i4a/pages/index.cfm?pageid=3341

Long, A. D., \& Perkins, D. D. (2003). Confirmatory factor analysis of the Sense of Community Index and development of a brief SCI. Journal of Community Psychology, 31 (3), 279-296. Retrieved from http://www.scra27.org/publications 
Maras, P. (2007). 'But no one in my family has been to university' Aiming higher: School students' attitudes to higher education. Australian Education Researcher, 34 (3), 69-90. Retrieved from http://www.aare.edu.au/live/index.php?option=com_content\&view $=$ article \&id=9 \&Itemid $=10$

Maslow, A. H. (1943). A theory of human motivation. Psychological Review, 50 (4), 370-396. Retrieved from http://www.apa.org/pubs/journals/rev/index.aspx

McCarthy, M., Pretty, G. H., \& Catano, V. (1990). Psychological sense of community and student burnout. Journal of College Student Development, 31 (3). 211-216. Retrieved from http://www.jcsdonline.org/

McMillan, D. W. (1976). Sense of community: An attempt at definition. Unpublished manuscript, George Peabody College for Teachers, Nashville, TN.

McMillan, D. W., \& Chavis, D. M. (1986). Sense of Community: A definition and a theory. Journal of Community Psychology, 14 (1), 6-23. Retrieved from http://www.scra27.org/publications

Nasir, N. S., Jones, A., \& McLaughlin, M. (2011). School connectedness for students in low-income urban high schools. Teachers College Record, 113 (8), 1755-1793. Retrieved from http://www.tcrecord.org/

Obst, P., Smith, S. G., \& Zinkiewicz, L. (2002). An exploration of sense of community, part 3: Dimensions and predictors of psychological sense of community in geographical communities. Journal of Community Psychology, 30 (1), 119-133. Retrieved from http://www.scra27.org/publications

Osterman, K. F. (2000). Students' need for belonging in the school community. Review of Educational Research, 70 (3), 323-367. Retrieved from http://www.aera.net/Publications/tabid/10067/Default.aspx

Overbaugh, R. C., \& Nickel, C. E. (2011). A comparison of student satisfaction and value of academic community between blendd and online sections of a university-level educational foundations course. Internet and Higher Education. 14 (3). 164-174. Retrieved from Retrieved from http://scis.nova.edu/

Pervin, L. A., Reik, L. E., \& Dalrymple, W. (1966). The college dropout and the utilization of talent. Princeton, New Jersey: Princeton University Press.

Prezza, M., \& Costantini, S. (1998). Sense of Community and life satisfaction: Investigation in three different territorial contexts. Journal of Community and Applied Social Psychology, 8 (3). 181-194. 
Reich, S. M. (2010). Adolescents' sense of community on Myspace and Facebook: A mixed-methods approach. Journal of Community Psychology, 38 (6), 688-705. Retrieved from http://www.babcp.com/Default.aspx

Relph, E. (1976). Place and placelessness. London: Pion.

Riger, S., \& Lavrakas, P. J. (1981). Community ties: Patterns of attachment and social interaction in urban neighborhoods. American Journal of Community Psychology, 9 (1), 55-66. Retrieved from http://www.apa.org/about/division/div27.aspx

Ritter, C., Polnick, B., Fink, R., \& Oescher, J. (2010). Classroom learning communities in educational leadership: A comparison study of three delivery options. Internet and Higher Education, 13 (1), 96-100. Retrieved from http://scis.nova.edu/

Rootman, I. (1972). Voluntary withdrawal from a total adult socializing organization: A model. Sociology of Education, 45 (3), 258-270. Retrieved from http://www.asanet.org/journals/soe/index.cfm

Rovai, A. P. (2002). Development of an instrument to measure classroom community. Internet and Higher Education, 5 (3), 197-211. Retrieved from http://scis.nova.edu/

Rovai, A. P. Wighting, M. J., \& Lucking, R. (2004). The Classroom and School Community Inventory: Development, refinement, and validation of a self-report measure for educational research. Internet and Higher Education, 7 (4), 263-280. Retrieved from http://scis.nova.edu/

Rowles, G. D. (1983).Place and personal identity in old age: Observations from Appalachia. Journal of Environmental Psychology, 3 (4), 299-313. Retrieved from http://www.sciencedirect.com/science/journal/02724944

Ryan, R. M. (1995). Psychological needs and the facilitation of integrative processes. Journal of Personality, 63 (3), 397-427. Retrieved from http://www.blackwellpublishing.com/journal.asp?ref=0022-3506

Salas, E. Rozell, D., Mullen, B., \& Driskell, J. E. (1999). The effect of team building on performance: An integration. Small Group Research, 30 (3), 309-329. Retrieved from http://scis.nova.edu/

Sarason, S. B. (1974). The Psychological Sense of Community: Prospects for a community psychology. Oxford, England: Jossey-Bass.

Serrano, J. M., \& Pons, R. M. (2007). Cooperative learning: We can also do it without task structure. Intercultural Education, 18 (3), 215-230. Retrieved from http://207.210.232.43/ u199080/publications.html 
Shaffer, C., \& Anundsen, K. (1993). Creating Community Anywhere. Watertown, ON, Canada: Penguin Putnam.

Shaw, M. B. (1981). Group dynamics: The psychology of group behavior (3 ${ }^{\text {rd }}$ ed.). New York: McGraw-Hill.

Sherblom, S. A, Marshall, J. C., \& Sherblom, J. C. (2006). The relationship between school climate and math and reading achievement. Journal of Research in Character Education, 4 (1 \& 2), 19-31. Retrieved from http://www.character.org/more-resources/publications/catalog/journal-ce/

Shouse, R. C. (1996). Academic press and sense of community: Conflict, congruence, and implications for student achievement. Social Psychology of Education, 1 (1), 47-68. Retrieved from http://www.springerlink.com/content/102995/?MUD=MP

Solomon, D., Watson, M., Battistich, V., Schaps, E., \& Delucchi, K. (1996). Creating classrooms that students experience as communities. American Journal of Community Psychology. 24 (6), 719-748. Retrieved from http://www.apa.org/about/division/div27.aspx

Tartaglia, S. (2006). A preliminary study for a new model of Sense of Community. Journal of Community Psychology, 34 (1), 25-36. Retrieved from http://www.scra27.org/publications

Tinto, V. (1975). Dropout from higher education: A theoretical synthesis of recent research. Review of Educational Research, 45 (1), 89-125. Retrieved from http://www.aera.net/Publications/tabid/10067/Default.aspx

Tradewell, T. W., Reisch, E. E., Travaglini, L. E., \& Kumar, V. K. (2011). The effectiveness of collaborative story building and telling in facilitation group cohesion a college classroom setting. International Journal of Group Psychotherapy, 61 (4), 502-517. Retrieved from http://www.groupsinc.org/pubs/index.html

Tuan, Y. (1974). Topophilia: A study of environmental perception, attitudes, and values. Englewood Cliffs, New Jersey: Pretince-Hall Inc.

van Knippenberg, D., \& Schippers, M. C. (2007). Work group diversity. Annual Review of Psychology, 58, 515-541. Retrieved from http://www.annualreviews.org/journal/psych

Voelkl, K. E. (1996). Measuring students' identification with school. Educational and Psychological Measurement, 56 (5), 760-770. Retrieved from http://epm.sagepub.com/ 
Walker, G. J., Deng, J. Y., \& Dieser, R. B. (2005). Culture, self-construal, and leisure theory and practice. Journal of Leisure Research, 37 (1), 77-99. http://www.nrpa.org/jlr/

Woodman, R. W., \& Sherwood, J. J. (1980). The role of team development in organizational effectiveness: A critical review. Psychological Bulletin, 88 (1), 166-186. Retrieved from http://www.apa.org/pubs/journals/bul/index.aspx

Whitlock, J. (2007). The role of adults, public space, and power in adolescent community connectedness. Journal of Community Psychology, 35 (4), 499-518. Retrieved from http://www.scra27.org/publications

Youniss, J., Yates, M., \& Su, Y. (1997). Social integration: Community service and marijuana use in high school seniors. Journal of Adolescent Research, 12 (2), 245-262. Retrieved from http://jar.sagepub.com/

Youniss, J., McLellan, J. A., Su, Y., \& Yates, M. (1999). The role of community service in identity development: Normative, unconventional, and deviant orientations. Jouranl of Adolescent Research, 14 (2), 248-261. Retrieved from http://jar.sagepub.com/

Zimmerman, M. A., \& Arunkumar, R. (1994). Resiliency research: Implications for schools and policy. Social Policy Report, 8 (4), 1-18. Retrieved from http://www.srcd.org/index.php?option=com_content\&task=view\&id=232\&Itemid $=658$ 
Appendix A 


\section{Instructor Interview}

Researcher: "Thank you for agreeing to participate in this short interview. My name is Alix and I am a master's student in the Recreation, Parks, and Tourism Administration Department. Your responses will be used in my thesis project. This interview should take approximately five minutes. Your participation is voluntary and you may opt to end the interview or omit any answers at any time. Your name and course number will not be reported or associated with any of your responses to these questions. The purpose of this study is to investigate the instructor's role in classroom community at Cal Poly. You have been selected in your capacity as the instructor of [course name and number], a course designed to introduce new students into the [major name]. Researchers have defined "Sense of Community" as the feeling of being part of a readily available, mutually supportive network of relationships upon which one can depend. There are a number of activities that may increase this feeling such as ice-breakers and name games."

1) To what extent do you feel that you have intentionally created a classroom environment in which students are connected to each other? Please answer 1-5, where 1 indicates "not at all" and 5 indicates "to a great extent"

$\begin{array}{ccccc}\text { Not at all } & \text { Very little } & \text { Somewhat } & \text { Quite a bit } & \text { To a great extent } \\ 1 & 2 & 3 & 4 & 5\end{array}$

2) Thinking back to the beginning of this quarter, have you conducted any activities that you feel were utilized with the purpose of create relationships between students in [course name]? Y N

3) If so, describe the activity(ies):

a. How much time was spent on this activity?

b. When in the quarter did this activity take place _Beginning __ Middle __ End __ Throughout

Thank you very much for your time and participation. 
Appendix B 


\section{Student Questionnaire}

Researcher: "Thank you all for participating in this study. My name is Alix and I am a master's student in the Recreation, Parks, and Tourism Administration Department. Your responses will be used in my thesis project. This questionnaire should take approximately ten minutes. Your participation is voluntary and anonymous and you may opt to omit any answers at any time. During this quarter your professor may or may or may not have conducted activities in this class that you feel were designed to help you bond and build relationships with each other. For this questionnaire I am asking you to think about your time throughout this quarter in this course and consider any of these activities. This questionnaire is broken up into three parts. Part 1 asks you to think about any activities that may have taken place during this course this quarter. Examples of these types of activities might range from something like an icebreaker, to classroom set up, to in or out of class projects. Part 2 asks you to think about your experience with your classmates in this course this quarter. Part 3 is some demographic information about you. You may use a pen or pencil. Thank you!" 
Appendix C 


\section{Investigating the Sense of Classroom Community at Cal Poly}

Please take a few minutes to fill out this questionnaire. The questionnaire is in three parts: Your participation is voluntary and responses are anonymous. Thank you for your time and participation.

\section{Part 1}

Part 1 asks you to think about any activities that may or may not have taken place during this course.

1. Course name and Number:

2. To what extent do you feel your professor has intentionally created a classroom environment where students are connected to each other? (Please circle one)

$$
\begin{array}{ccccc}
\text { Not at all } & \text { Very Little } & \text { Somewhat } & \text { Quite a bit } & \text { To a great extent } \\
1 & 2 & 3 & 4 & 5
\end{array}
$$

3. If your professor conducted any activities that you believe were intended to create connections between students, for each activity, state whether you feel that the activity was i) enjoyable and ii) effective in building a sense of classroom community. For each activity indicate iii) the amount of time spent on the activity and iv) when in the quarter the activity took place

\section{a. Activity}

i. Was the activity enjoyable: (Please check one) __ Yes No

ii. How effective was the activity in building classroom community:

(Please circle one)

$\begin{array}{ccccc}\text { Not at all } & \text { A little } & \text { Somewhat } & \text { Quite } & \text { Very } \\ 1 & 2 & 3 & 4 & 5\end{array}$

iii. Amount of time spent on activity:

iv. When in the quarter did this activity take place? (Please check one) Beginning ___ Middle__End__ Throughout 


\section{b. Activity}

i. Was the activity enjoyable: (Please check one)__ Yes ___ No

ii. How effective was the activity in building classroom community: (Please circle one)

Not at all Very Little Somewhat Quite a bit To a great extent 2 3 4 5

iii. Amount of time spent on activity:

iv. When in the quarter did this activity take place? (Please check one) Beginning ___ Middle___End__ Throughout

c. Activity

i. Was the activity: (Please check one) ___ Yes__ No

ii. How effective was the activity in building classroom community: (Please circle one)

Not at all Very Little Somewhat Quite a bit To a great extent 1 $2 \quad 3$ $4 \quad 5$

iii. Amount of time spent on activity:

iv. When in the quarter did this activity take place? (Please check one) Beginning Middle End Throughout 


\section{d. Activity}

i. Was the activity enjoyable: (Please check one)___ Yes ___ No

ii. How effective was the activity in building classroom community: (Please circle one)

$\begin{array}{ccccc}\text { Not at all } & \text { Very Little } & \text { Somewhat } & \text { Quite a bit } & \text { To a great extent } \\ 1 & 2 & 3 & 4 & 5\end{array}$

iii. Amount of time spent on activity:

iv. When in the quarter did this activity take place? (Please check one) Beginning __ Middle__End_Throughout

e. Activity

i. Was the activity enjoyable: (Please check one)__ Yes ___ No

ii. How effective was the activity in building classroom community: (Please circle one) $\begin{array}{ccccc}\text { Not at all } & \text { Very Little } & \text { Somewhat } & \text { Quite a bit } & \text { To a great extent } \\ 1 & 2 & 3 & 4 & 5\end{array}$ 4

iii. Amount of time spent on activity:

iv. When in the quarter did this activity take place? (Please check one) Beginning ___ Middle___End__ Throughout

Please feel free to include any additional activities on the back of this packet. 


\section{Part 2}

Part 2 asks you to think about your experience with your classmates in this course.

4. Below, you will see a series of statements concerning the course you are presently taking. Read each statement carefully and place an $\mathrm{X}$ in the parentheses to the right of the statement that comes closest to indicating how you feel about the course or program. There are no correct or incorrect responses. If you neither agree nor disagree with a statement or are uncertain, place an $\mathrm{X}$ in the neutral $(\mathrm{N})$ area. Do not spend too much time on any one statement, but give the response that seems to describe how you feel. Please respond to all items.

Strongly Agree Neutral Disagree Strongly Agree (SA) (A)

$(\mathrm{N})$

a. I feel that students in this course care about each other

b. I feel that I am encouraged to ask questions

c. I feel connected to others in this course

d. I feel that it is hard to get help when I have a question

e. I do not feel a spirit of community

f. I feel that I receive timely feedback

g. I feel that this course is like a family

$\mathrm{h}$. I feel uneasy exposing gaps in my understanding

i. I feel isolated in this course

j. I feel reluctant to speak openly

k. I trust others in this course

1. I feel that this course results in only modest learning

$\mathrm{m}$. I feel that I can rely on others in this course

n. I feel that other students do not help me learn

o. I feel that members of this course depend on me

p. I feel that I am given ample opportunities to learn

q. I feel uncertain about others in this course

r. I feel that my educational needs are not being met

s. I feel confident that others will support me

t. I feel that this course does not promote a desire to learn

\section{(SA)}

(SA)

(SA)

(SA)

(SA)

(SA)

(SA)

(SA)

(SA)

(SA)

(SA)

(SA)

(SA)

(SA)

(SA)

(SA)

(SA)

(SA)

(SA)

(SA)

\section{(A)}

(A)

(A)

(A)

(A)

(A)

(A)

(A)

(A)

(A)

(A)

(A)

(A)

(A)

(A)

(A)

(A)

(A)

(A)

(A)
(D) (SD)

(N)

(N)

(N)

(N)

(N)

(N)

(N)

(N)

(N)

(N)

(D)

(D)

(D)

(D)

(D)

Disagree 


\section{Part 3}

Part 3 asks for some demographic information about you.

5. What is your year in school? (Please check one) ___Freshman ___ Sophomore Junior_Senior___ Graduate

6. Is this your first quarter at Cal Poly? (Please check one) __ Yes __ No

7. Is this your first quarter at any college/university? (Please check one) __ Yes __ No

8. What is your major?

9. Are you taking this class for (Please check one): ___ Major requirement Elective

10. How many students did you know in this class before it started?

11. Have you had any other classes with this instructor? (Please check one) Yes No

12. Gender (please check one) __ Male __ Female __ Other 